January 2021

\title{
Cross-Jurisdictional Analysis of Damage Awards in Copyright Infringement Cases
}

Ioana Vasiu

Babeş-Bolyai University

Lucian Vasiu

Follow this and additional works at: https://digitalcommons.law.uga.edu/jipl

Part of the Intellectual Property Law Commons

\section{Recommended Citation}

Ioana Vasiu \& Lucian Vasiu, Cross-Jurisdictional Analysis of Damage Awards in Copyright Infringement Cases, 28 J. INTELL. PROP. L. (2021).

Available at: https://digitalcommons.law.uga.edu/jipl/vol28/iss1/4

This Article is brought to you for free and open access by Digital Commons @ University of Georgia School of Law. It has been accepted for inclusion in Journal of Intellectual Property Law by an authorized editor of Digital Commons @ University of Georgia School of Law. Please share how you have benefited from this access For more information, please contact tstriepe@uga.edu. 


\section{Cross-Jurisdictional Analysis of Damage Awards in Copyright Infringement Cases}

\section{Cover Page Footnote}

Prof. Dr. loana Vasiu is Vice Dean and Coordinator of the Cybercrime Research Unit, Faculty of Law, Babeş-Bolyai University (BBU); member of the Board of Directors of the International Association of Penal Law (2014-2024); member of the BBU Scientific Council; and external affiliated member of the Ostrom Workshop Program on Cybersecurity and Internet Governance, Indiana University. Her past professional experiences include: expert for the European Commission and the UNDP Romania; partner and lead researcher on several projects funded by the European Commission, the Dutch Council for the Judiciary, and other entities; co-Chair of the Management and Delivery of Justice Group of the European Group of Public Administration; and keynote speaker or moderator at numerous professional events. 


\title{
CROSS-JURISDICTIONAL ANALYSIS OF DAMAGE AWARDS IN COPYRIGHT INFRINGEMENT CASES
}

\author{
Ioana Vasiu* \& Lucian Vasiu
}

\begin{abstract}
* Prof. Dr. Ioana Vasiu is Vice Dean and Coordinator of the Cybercrime Research Unit, Faculty of Law, Babeş-Bolyai University (BBU); member of the Board of Directors of the International Association of Penal Law (2014-2024); member of the BBU Scientific Council; and external affiliated member of the Ostrom Workshop Program on Cybersecurity and Internet Governance, Indiana University. Her past professional experiences include: expert for the European Commission and the UNDP Romania; partner and lead researcher on several projects funded by the European Commission, the Dutch Council for the Judiciary, and other entities; co-Chair of the Management and Delivery of Justice Group of the Europeann Group of Public Administration; and keynote speaker or moderator at numerous professional events.
\end{abstract}


Journal of Intellectual Property Law, Vol. 28, Iss. 1 [2021], Art. 4

\section{TABLE OF CONTENTS}

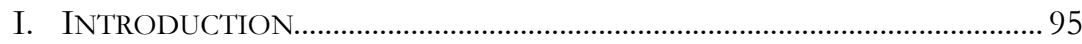

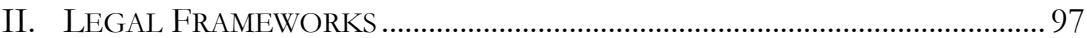

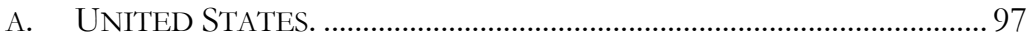

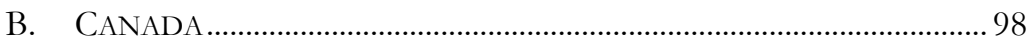

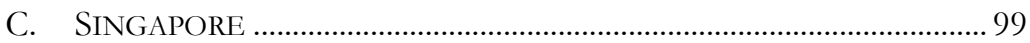

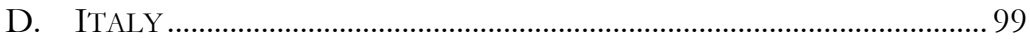

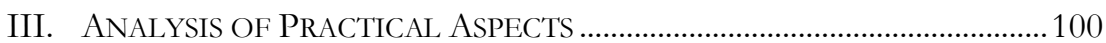

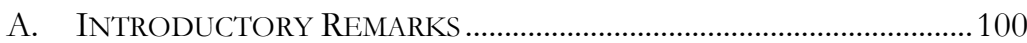

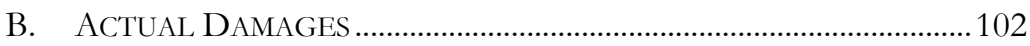

1. Lost Profits....................................................................................... 103

2. Royalties ………………….............................................................. 105

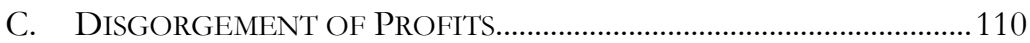

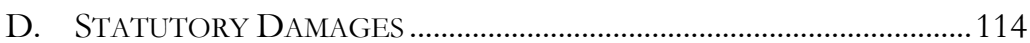

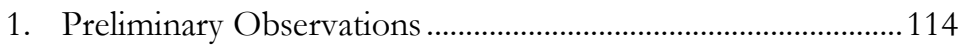

2. Amount of the Award ...................................................................116

3. Number of Works Infringed......................................................... 118

4. Enhanced Awards ......................................................................... 120

5. Award Adjustment.................................................................... 124

E. Punitive DAMAGES .............................................................................. 124

IV. Summary OF THE FindingS AND Proposals.........................................128

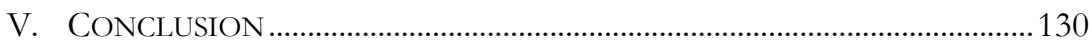




\section{INTRODUCTION}

Copyright and related rights are economic and moral. The infringement of economic rights is a widespread phenomenon that produces massive financial losses to stakeholders. ${ }^{1}$ All species of protected works are vulnerable to infringements: computer programs; ${ }^{2}$ photographs; ${ }^{3}$ films; ${ }^{4}$ songs; ${ }^{5}$ books; ${ }^{6}$ databases $;{ }^{7}$ cartoon characters $;{ }^{8}$ images of people; $;$ architectural works; $;{ }^{10}$ charts $;{ }^{11}$ drawings; ${ }^{12}$ patterns; ${ }^{13}$ etc. The range of relief in cases of infringement of copyright-protected works includes monetary damages.

There is a large academic literature that discusses various aspects regarding damage awards for copyright infringements. ${ }^{14}$ However, existing literature does

1 Regarding entertainment, see, e.g., David Blackburn et al., Impacts of Digital VideO PiRACY ON THE U.S. ECONOMY (2019), https://www.theglobalipcenter.com/wpcontent/uploads/2019/06/Digital-Video-Piracy.pdf (digital video piracy accounts for about 26.6 billion movie viewings and 126.7 billion TV program viewings, thus reducing the U.S. gross domestic product by an amount between $\$ 47.5$ billion and $\$ 115.3$ billion); European Union Intellectual Prop. Office, Illegal PTV in the European Union (Nov. 2019), https://euipo.europa.eu/tunnel-

web/secure/webdav/guest/document_library/observatory/documents/reports/2019_Illega 1_IPTV_in_the_European_Union/2019_Illegal_IPTV_in_the_European_Union_Full_en.p df (in 2018 , the infringing IPTV content generated $€ 941.7$ million in revenues); MOTION Picture Association of America, Review of Notorious Markets (2018) at 2, https://www.motionpictures.org/wp-content/uploads/2018/11/notorious-markets-

final.pdf ("In 2016, there were an estimated 21.4 billion total visits to streaming piracy sites worldwide”); PCCW Media Ltd v. M1 Ltd [2018] SGHC 99 (Sing.) (unauthorized streaming of drama or variety shows, receiving hundreds of thousands to millions of visits monthly in Singapore); United States v. Batato, 833 F.3d 413, 418 (4th Cir. 2016) (the infringers caused an estimated harm of "well in excess of $\$ 500,000,000$ " to copyright owners, by the illegal reproduction and distribution of copyrighted movies, television programs, and music).

2 Adobe Sys. Inc. v. SKH Sys., Inc., No. A-17-CA-018-SS, 2017 WL 6611513 (W.D. Tex. Dec. 27, 2017).

3 Spinelli v. Nat'l Football League, 903 F.3d 185 (2d Cir. 2018).

4 Disney Enters., Inc. v. M1 Ltd [2018] SGHC 206 (Sing.).

5 Marshall v. Babbs, No. 2:18-cv-03822-DDP-AFMx (C.D. Cal. May 15, 2020).

6 John Wiley \& Sons, Inc. v. Book Dog Books, LLC, 327 F. Supp. 3d 606 (S.D.N.Y. 2018).

7 Infogroup, Inc. v. DatabaseUSA.com LLC, 956 F.3d 1063 (8th Cir. 2020).

8 Wrench LLC v. Taco Bell Corp., 256 F.3d 446 (6th Cir. 2001).

9 See Trib. Torino, 27 febbraio 2019, n. 940/2019 (It.) (sentencing a company for the illicit use of the image of Audrey Hepburn on clothing marketed by the same company without consent to the use of the portrait of the actress by legitimate subjects).

10 Lainco Inc. v. Commission Scolaire Des Bois-Francs, [2017] F.C. 825 (Can.).

11 Enter. Mgmt. Ltd., Inc. v. Construx Software Builders, Inc., No. 2:19-CV-1458-DWC (W.D. Wash. May 29, 2020).

121422986 Ontario Ltd. v. 1833326 Ontario Ltd., 2020 O.N.S.C. 1041 (Can.).

13 Hamil Am., Inc. v. GFI, 193 F.3d 92 (2d Cir. 1999).

14 See Ben Depoorter, Copyright Enforcement in the Digital Age: When the Remedy is the Wrong, 66 UCLA L. REV. 400 (2019) (analyzing 102 judicial decisions on copyright statutory damages 
DeMO2 (Do Not DeleTE) 1 1/12/2021 5:42 AM

not provide a comprehensive analysis of the award of damages in these cases. Based on extensive examination of over four hundred cases, this article aims to provide a comprehensive cross-jurisdictional analysis of damage awards in copyright infringement cases.

This research employed a multi-step research methodology: selecting jurisdictions, case content analysis, development and refinement of an analytical framework, cross-case, and cross-jurisdictional analysis. Based on the review of multiple legal frameworks and relevant cases, the jurisdictions selected are the United States (U.S.), ${ }^{15}$ Canada, Singapore, and Italy. The study of cases from the selected jurisdictions employed content analysis, with a view to systematically identify prominent attributes and arguments, used for thematic grouping into an analytical framework, comprising types, factors, methodologies, and viewpoints, that structured the research. The cross-analysis aimed to highlight the most important aspects, similarities, and differences in how courts across the four jurisdictions award damages in copyright infringement cases. Based on the findings of the cross-analysis, the article proposes a number of potential improvements for the award of damages.

The article proceeds in three parts. Part I discusses the legal frameworks. Part II, structured in five sections, discusses practical aspects regarding

over the 2005-2008 period); Abraham Bell \& Gideon Parchomovsky, Restructuring Copyright Infringement, 98 TEx. L. REV. 679 (2020) (proposing a copyright infringement liability regime predicated on infringer's degree of blameworthiness); Scott J. Sholder \& Lindsay R. Edelstein, Determining a Reasonable Licensing Fee for Purposes of Copyright Damage Awards, 27 BRIGHT IDEAS 13 (2018) (discussing aspects pertaining to the calculation of damages based on licensing fees); Yasuhiro Ikeda \& Daisuke Mori, Can Decoupling Punitive Damages Deter an Injurer's Harmful Activity?, 11 REV. L. ECON. 513 (2015) (analyzing the decoupling of punitive damages under the adversarial system); John Y. Gotanda, Punitive Damages: A Comparative Analysis, 42 Colum. J. TRANSNAT'L L. 391 (2003) (discussing aspects regarding the award of punitive damages); Vanessa Yu, Note, Calculating Statutory Damages in Copyright Infringement Cases: What Constitutes "One Work"?, 58 SANTA CLARA L. REV. 375 (2018) (analyzing aspects concerning the interpretation of the "one-work limitation" of Section 504); David Nimmer, Investigating the Hypothetical "Reasonable Royalty" for Copyright Infringement, 99 B.U. L. REV. 1 (2019) (discussing aspects regarding the award of monetary damages based on a hypothetical royalty); Pamela Samuelson, Phil Hill \& Tara Wheatland, Statutory Damages: A Rarity in Copyright Laws Internationally, But For How Long?, 60 J. COPYRIGHT SOC'Y U.S.A. 529 (2013) (exploring the statutory damages provisions differences in several countries); Gordon I.D. Llewelyn, Assessment of Damages in Intellectual Property Cases: Some Recent Examples of "the Exercise of a Sound Imagination and the Practice of a Broad Axe"?, 27 SINGAPORE ACAD. L.J. 480 (2015) (analyzing the award of statutory damages in Singapore).

15 The United States is the world leader in copyright protections. See Erin Duffin, GIPC International Intellectual Property Index 2020, STAтіsтA.com (Mar. 4, 2020), https://www.statista.com/statistics/257583/gipc-international-intellectual-property-index/ (the leading country for the best intellectual property environment was the United States); 2019 International Property Rights Index Released, Property Rights Alliance (Oct. 16, 2019), https://www.propertyrightsalliance.org/news/2019-international-property-rights-indexpress-release-draft/ (U.S. leads the world in copyright protection). 
compensatory and punitive awards. Part III discusses the implications of the findings and proposes a number of potential improvements.

\section{LEGAL FRAMEWORKS}

The Agreement on Trade-Related Aspects of International Property Rights (TRIPS) requires member states to give courts the authority to "order the infringer to pay the right holder damages adequate to compensate for the injury the right holder has suffered." 16 In these actions, damages are awarded under a combination of compensatory damages, which comprises copyright owner's actual damages, royalties, and infringer's profits, or statutory damages, and punitive damages.

\section{A. UNITED STATES}

The U.S. Copyright Act (USCA) authorizes the recovery of the copyright owner's actual damages and any profits made by the infringer, not considered in the award of actual damages, or statutory damages. ${ }^{17}$ The plaintiff is required to prove infringer's gross revenue, while the defendant is required to demonstrate any deductible expenses claimed and the elements of profit that can be attributed to other factors than the infringement of the work in the case. ${ }^{18}$

Statutory damages can range from $\$ 750$ to $\$ 30,000$ per act of infringement, ${ }^{19}$ or, when increased or enhanced damages are awarded, up to $\$ 150,000$ per willful infringement. ${ }^{20}$ Copyright owners are entitled to statutory damages only if the registration of the work predates the first infringement. ${ }^{21}$ A defendant's knowledge or intent is irrelevant to their liability for copyright infringement. ${ }^{22}$ If the infringer, however, "was not aware and had no reason to believe that his or her acts constituted an infringement of copyright," the award of statutory damages may be as low as $\$ 200 .^{23}$

The amount of statutory damages is determined by a jury. ${ }^{24}$ The USCA does not contain provisions for punitive damages, however, these are awarded, in addition to compensatory damages, for their general conduct deterrence role.

16 Trade-Related Aspects of International Property Rights, Art. 45.1.

1717 U.S.C. $\int 504$ (a) (2010).

18 17 U.S.C. $\int 504(\mathrm{~b})(2010)$.

1917 U.S.C. $\$ 504(\mathrm{c})(1)(2010)$.

2017 U.S.C. $\$ 504$ (c) (2) (2010) (if the "infringer was not aware and had no reason to believe that his or her acts constituted an infringement of copyright," statutory damages may be reduced to \$200).

2117 U.S.C. $\int 412(2008)$.

2217 U.S.C. $\$ 501$ (a) (2019).

2317 U.S.C. $\$ 504(c)(2)(2010)$.

24 Feltner v. Columbia Pictures Television, Inc., 523 U.S. 340, 355 (1998). 


DeMO2 (Do Not DeleTE) 1 1/12/2021 5:42 AM

Enhanced or punitive damages, however, can be only be awarded if the copyright owner is entitled to statutory damages. ${ }^{25}$

\section{B. CANADA}

The Canada Copyright Act (CCA) provides for awards of actual damages and "such part of the profits that the infringer has made from the infringement and that were not taken into account in calculating the damages as the court considers just." 26 The claimant is required to demonstrate "only receipts or revenues derived from the infringement," while the defendant must prove the cost elements. ${ }^{27}$

Instead of actual damages and profits, the copyright owner can elect an award for statutory damages, "[F]or which any one infringer is liable individually, or for which any two or more infringers are liable jointly and severally," ranging from $\mathrm{C} \$ 500$ to $\mathrm{C} \$ 20,000$, for each work, in the case of infringements made for commercial purposes, and from $\mathrm{C} \$ 100$ to $\mathrm{C} \$ 5,000$, for all works, for non-commercial infringements. ${ }^{28}$

CCA stipulates limitations on the award of statutory damages to a collecting society: "not less than three and not more than ten times the amount of the applicable royalties ...."29 CCA also provides for a cap in statutory damages, lower than $\$ 500$ per work, in cases where there are more than one work in a single medium or the award relates only to one or more infringements under subsection $27(2.3)$ and the award, even when the minimum is granted, amounts to a total that is considered "grossly out of proportion to the infringement." 30

An election of statutory damages does not affect the right of the copyright owner to punitive damages. ${ }^{31}$ Punitive damages can be awarded in cases where the defendant is found guilty of "high-handed, malicious, arbitrary or highly reprehensible misconduct that departs to a marked degree from ordinary standards of decent behaviour." 32 CCA lists factors that can be used to determine the adequate or proportional amount of statutory damages: defendant's faith and conduct before and during the proceedings; the deterrent effect on other infringements; and the particular considerations in cases of non-commercial infringements. ${ }^{33}$ The election of statutory damages does not affect the copyright owner's right to receive exemplary or punitive damages. ${ }^{34}$

2517 U.S.C. $\$ 504(c)(2)(2010)$

26 Canadian Copyright Act (“CCA”), R.S.C. 1985, c. C-42, art 35(1).

27 CCA 35(2).

28 CCA 38.1(1).

29 CCA 38.1(4).

30 CCA 38.1(3)(b).

31 CCA 38.1(7).

32 Whiten v. Pilot Ins. Co., 2002 SCC 18 para. 597 (Can.).

33 CCA 38.1(5).

34 CCA 38.1(7). 


\section{SINGAPORE}

The Singapore Copyright Act (SCA) provides relief in the form of damages and profits, attributable to the infringement, not taken into account in computing the damages, or statutory damages of up to $\$ \$ 10,000$ for each work or subject matter, for a maximum aggregated total of $\$ \$ 200,000$, except when the actual losses of the plaintiff exceeds that amount. ${ }^{35}$ If, at the time of infringement, a defendant was not aware and had no reasonable suspicion that his or her acts constituted copyright infringement, the plaintiff cannot claim any damages but is entitled to profits resulting from the infringement. ${ }^{36}$

The SCA lists factors that should be considered in awarding statutory damages: nature and purpose of the infringement; flagrancy of the act; defendant's bad faith; amount of loss caused or likely to occur as the result of the infringement; benefit accrued by the defendant; conduct before and during the proceedings; deterrent effect; and other relevant aspects. ${ }^{37}$ An award of exemplary damages is possible.

\section{ITALY}

Law No. $633^{38}$ provides the possibility for copyright owners to receive damages that cover both the right holder's damage and loss of profit, as long as these are a direct and immediate consequence of the infringement. ${ }^{39}$ The restitution of the illicit profits aims to punish the defendant and to dissuade others from emulating such illegal conduct. ${ }^{40}$ The compensation due to the injured party is settled according to the provisions of Article 1223, 1226, and 1227 of the Civil Code. ${ }^{41}$ The lost profits are assessed by the judge, as equitable settlement, after an evaluation of the actual circumstances, pursuant to Article 2056 of the Civil Code. ${ }^{42}$ The judge can also award damages on a flat-rate basis, based at a minimum on the amount that the infringer would have paid the owner to use the work in the case. ${ }^{43}$

While the body of the Italian case law on the disgorgement of illicit profits is

35 SCA $119(2)$

36 SCA 119(3).

37 SCA $119(5)$.

38 Legge 22 aprile 1941, n. 633, G.U. 16 Jul. 1941, n.166 (It.).

39 L. n. 633/1941, Art. 158 (It.); see also Art. 125(2) of the Italian Industrial Property Code (Codice di Proprietà Industriale).

40 Paolo Pardolesi, Disgorgement of Profits: Gain-Based Remedies Throughout THE World 495 (E. Hondius \& A. Janssen, eds., Springer 2015).

41 L. n. 633/1941, Art. 158 (It.).

42 Id.

43 Id. 


DeMO2 (Do Not DeleTE) 1 1/12/2021 5:42 AM

not very rich, it does provide some interesting cases for analysis. ${ }^{44}$ To assess damages, courts can admit technical experts. There is no limit set on the amount of damages. Dual damages or other forms of punitive damages are not awarded under Italian law.

\section{ANALYSIS OF PRACTICAL ASPECTS}

\section{A. INTRODUCTORY REMARKS}

Copyright owners have the exclusive rights to reproduce, perform or display publicly, produce derivative works of, and distribute copies of their protected works. Permissions regarding these rights can be acquired legitimately under an implied license, ${ }^{45}$ or through various authorization or licensing models or mechanisms. ${ }^{46}$ Licensing can be direct, or through licensing agencies, and subject to a number of terms and conditions.

The terms of a license agreement define a number of things, such as the scope of the license and type of qualifying users (e.g., commercial, educational, etc.); type and location of permitted installation, distribution, transfer, or media use, and under what conditions; time-limits of permissions; rights and restrictions regarding the exploitation or royalties; payment of fees; etc. As such, there are numerous forms of agreements, for instance, Preferred Pricing Agreement (PPA); ${ }^{47}$ Software License Agreement (SLA);48 Enterprise Licensing Agreement (ELA); ${ }^{49}$ End User License Agreement (EULA); ${ }^{50}$ Software License Agreement

44 PARDOLESI, supra note 40, at 155.

45 Ahadams \& Co., P.C. v. Spectrum Health Servs., 40 F. Supp. 3d 456 (E.D. Pa. 2014) (explaining that defendants' use of the work fell within the scope of an implied license).

46 Unlicensed access or use of copyright-protected works do not infringe owner's exclusive rights if they are allowed by the statutory exceptions and limitations. See Twentieth Century Music Corp. v. Aiken, 422 U.S. 151, 151-155, 95 S. Ct. 2040, 45 L. Ed. $2 d 84$ (1975) ("No license is required by the Copyright Act, for example, to sing a copyrighted lyric in the shower."). On the other hand, there can be license agreements which comprise multiple licensing models or options, which can be invoked in copyright infringement claims, see, e.g., Micro Focus (US), Inc. v. Express Scripts, Inc., Civil Action No. PX-16-0971 (D. Md. Feb. 12, 2019).

47 See Krist v. Scholastic, Inc., 415 F. Supp. 3d 514 (E.D. Pa. 2019) (noting that the PPA contains provisions regarding the price and the terms concerning permissible uses of photographs, based on a number of factors, such as image size and territory envisaged for the exploitation of the publication).

48 See Vernor v. Autodesk, Inc., 621 F.3d 1102 (9th Cir. 2010) (noting that the SLA imposes significant transfer, use, and termination restrictions).

49 Microsoft Corp. v. Bio-Reference Lab'ys, Inc., Civil Action No. 16-2291 (ES)(JAD) (D.N.Y. Mar. 29, 2017) (noting that the defendant, part of the Microsoft volume licensing program, used software without paying the due compensation to the rights owner).

50 See Micro Focus (US), Inc. v. Genesys Software Sys., Inc., Civil Action No. 14-14049NMG (D. Mass. July 21, 2015) (explaining that the terms of the EULA stipulated that the 
(SLA); 51 Transactional Licensing Program (TLP);52 Original Equipment Manufacturer (OEM);53 Registered Refurbisher Program (RRP); ${ }^{54}$ Master License Agreement (MLA); 55 etc.

Courts have found that claims for breach of contract, in the licensing context, are not preempted by the Copyright Act. ${ }^{56}$ Therefore, the breach of the terms of a license agreement can lead to copyright infringement actions. ${ }^{57}$ However, copyright infringement claims are not necessarily accompanied by a contract, and, "symmetrically, a breach of contract is not by itself a tort or copyright violation." 58 An action that claims breach of a contract implied-in-law requires the demonstration of an act, performed by the defendant, which infringed a copyright exclusive right. ${ }^{59}$ In comparison, in an action that claims breach of a contract implied-in-fact, the claimant is required to prove "the extra element of a promise to pay for the use of the work which is implied from the conduct of

software can be exploited solely for "internal use and benefit," subject to certain narrow exceptions, regarding outsourcing, hosting data processing services to other parties, transfer the software to third parties, etc.).

51 See Adobe Sys. Inc. v. Blue Source Grp., Inc., 125 F. Supp. 3d 945, 971 (N.D. Cal. 2015) (explaining that certain software can be distributed only to customers who provide proof of qualification).

52 See Adobe Sys. Inc. v. Software Tech, No. 5:14-cv-02140-RMW, 2016 WL 4728119, at *6 (N.D. Cal. Nov. 10, 2015) (resulting from the defendant selling products outside plaintiff's licensing restrictions).

53 See Adobe Sys. Inc. v. A \& S Electronics, Inc., 153 F. Supp. 3d 1136, 1140 (N.D. Cal. 2015) (holding that the software could be distributed only as a bundle, with certain hardware elements).

54 See Microsoft Corp. v. Buy More, Inc., 136 F. Supp. 3d 1148, 1151 (C.D. Cal. 2015) (approving computers refurbished professionally, with properly licensed copies of the Microsoft programs).

55 See Phoenix Techs. Ltd. v. VMware, Inc., 195 F. Supp. 3d 1096, 1098 (N.D. Cal. 2017) (resulting from the plaintiff alleged that the defendant's products infringed the MLA terms, such as running on servers, operating with their host kernel, and supporting multiple processors).

56 Micro Focus (U.S.), Inc. v. Genesys Software Sys., Inc., Civil Action No. 14-14049NMG, 2015 WL 4480358, at *1 (D. Mass. July 21, 2015).

57 See generally VHT, Inc. v. Zillow Grp., Inc., 918 F.3d 723 (9th Cir. 2019) (resulting from the plaintiff claiming infringement of photos after the sale of a real estate property, based on the license agreement provision that authorized the use of the photos only in relation to the property sale); Sun Ent. Corp. v. Music World Music, LLC, No. 3:11-00625, 2012 WL 2812681 (M.D. Tenn. July 10, 2012) (resulting from the plaintiff not receiving the monetary entitlement under the terms of the Agreement and filing a copyright infringement and breach of contract Complaint). See also the judgment of the Court of Justice of the European Union (CJEU) in IT Dev. SAS v. Free Mobile SAS, Case C-666/18 (holding the breach of a license agreement was to be within the concept of "infringement of intellectual property rights").

58 SAS Inst., Inc. v. World Programming Ltd., 874 F.3d 370, 390 (4th Cir. 2017).

59 See 17 U.S.C. $\$ 106$ (2018) (enumerating the exclusive rights in copyrighted works). 


Demo2 (Do Not Delete) $1 / 12 / 2021 \quad 5: 42$ AM

the parties." ${ }^{\circ 0}$

Compensatory awards aim to bring "monetary relief," to redress the harms caused by the defendant's wrongful conduct (to "make the victim whole," or to get the claimants to where they would have been if the infringement had not happened). ${ }^{61}$ Compensatory damages in cases of copyright infringement can consist of actual damages (the results of the infringement) and the net profits of the infringer (attributable to the infringement and not duplicative of the actual damages award), or where available, statutory damages, calculated for each infringement.

\section{B. ACTUAL DAMAGES}

Actual damages are awards that compensate for proven losses, which occurred as a consequence of the infringing activity. These damages express the difference between the current position of the claimant and the position of where they would have been, absent the infringement.

Actual damages, often difficult to demonstrate even when they are substantial, can comprise a number of aspects, such as lost revenues (including, for instance, proceeds from customers induced by the infringement to take their business to the defendants, instead of the plaintiffs); ${ }^{62}$ reputation or goodwill damage, ${ }^{63}$ loss of competitive advantage; ${ }^{64}$ diminished work exploitation opportunities ${ }^{65}$ or value; ${ }^{66}$ cancellation of contracts; ${ }^{67}$ violation of contracts; ${ }^{68}$ etc. This section discusses the most important aspects in the calculation of these damages: lost

60 Wrench LLC v. Taco Bell Corp., 256 F.3d 446, 459 (6th Cir. 2001).

61 TVT Records v. Island Def Jam Music Grp., 279 F. Supp. 2d 413, 422 (S.D.N.Y. 2003) ("П]nsofar as recompense for injury may be achieved practically and fairly through monetary satisfaction.").

62 Digby Adler Grp. LLC v. Image Rent a Car, Inc., 79 F. Supp. 3d 1095 (N.D. Cal. 2015).

63 For instance, reputation damage due to inferior quality of counterfeit products, see Gianni Versace SPA v. 1154970 Ontario Ltd., [2003] F.C. 1015 (Can.); see also Microsoft Corp. v. Buy More, Inc., 136 F. Supp. 3d 1148 (C.D. Cal. 2015) (expressing the damage as goodwill damage, as unsuspecting customers received counterfeited disks with adulterated Registered Refurbisher Program Certificate of Authenticity, instead of the genuine software).

64 Texkhan, Inc. v. I Joah, No. 2:18-cv-09313-ODW (MRWx), 2019 WL 3974099, at *2 (C.D. Cal. Aug. 22, 2019) (noting that the plaintiff highlighted that its competitive advantage relies on the exclusivity of its copyright-protected designs).

65 On Davis v. The Gap, Inc., 246 F.3d 152, 176 (2d Cir. 2001).

66 Pierson v. DoStuff Media, LLC, No. A-19-CV-00435-LY, 2019 WL 5595236, at *1 (W.D. Tex. Oct. 29, 2019) (explaining that the plaintiff alleged that, as consequence of the defendant's copying of the copyright-protected work, the authorized commercial market for her work was diminished).

67 Harper \& Row, Publishers, Inc. v. Nation Enters., 471 U.S. 539, 542, 105 S. Ct. 2218 (1985).

68 Complaint at 97 , Schroeder et al. v. Volvo Grp. N. Am., LLC, Case 2:20-cv-05127 (C.D. Cal. June 9, 2020). 
profits, royalties, and disgorgement of the profits made by the infringer.

\section{Lost Profits}

The term "actual damages" is not defined in the Copyright Acts of the jurisdictions considered in this study, thus leaving the courts to find or define guidelines, norms, or methods for the calculation of these damages. ${ }^{69}$ In the U.S., for example, courts use several definitions in this sense: an actual damages award "undertakes to compensate the owner for any harm he suffered by reason of the infringer's illegal act;" 70 actual damages "are usually determined by the loss in the fair market value of the copyright, measured by the profits lost due to the infringement or by the value of the use of the copyrighted work to the infringer." ${ }^{\prime \prime}$

"Lost profits," the "quintessential example" of consequential damage, ${ }^{72}$ represent profits that the copyright proprietor, as a result of the infringement, failed to earn. The nexus between the lost profits and the infringement must be established with reasonable probability. The invalidation of lost profits claims is possible only if the defendant demonstrates that the loss would have occurred anyway, even absent the infringement (e.g., due to adverse market conditions, products launched by competitors, other infringements, etc.). As a way to avoid double recovery, damages for lost profits will not be awarded in cases where the disgorgement of the profits obtained by the defendant is considered..$^{73}$

There are numerous methods that can be employed to calculate lost profits, as these depend on various circumstances, such as the means and territorial scope of work exploitation, and current market conditions or perspectives. The calculation of the lost profits can also consider, for instance, the sales for a period, before the infringement, and compare that figure to the sales subsequent to the infringement, or use the infringer's sales as a base.

While the calculation of the lost profits is an "inexact science," 74 and no "mathematical exactness" 75 is required, actual claims must be expressed in numbers approximated with reasonable certainty. These claims, however, are assessed "skeptically," as market performance is often difficult to predict, and does change, therefore, causation is not always a straightforward analysis, and the calculation of projected sales may be construed as unduly speculative by courts. ${ }^{76}$

\footnotetext{
69 Storm Impact, Inc. v. Software of Month Club, 13 F. Supp. 2d 782, 791 (N.D. Ill. 1998).

70 On Davis v. The Gap, Inc., 246 F.3d 152, 159 (2d Cir. 2001).

71 McRoberts Software, Inc. v. Media 100, Inc., 329 F.3d 557, 566 (7th Cir. 2003).

72 Casa Dimitri Corp. v. Invicta Watch Co., 270 F. Supp. 3d 1340, 1352 (S.D. Fla. 2017).

73 Paragon Testing Enters. Inc. v. Lee, Judgement, 2018 BCSC 634, at 33 (Apr. 2018) (Can.).

74 United States v. Sterling, 685 Fed. App'x. 880, 885 (11th Cir. 2017).

75 Universal Pictures v. Harold Lloyd Corp., 162 F. 2d 354, 370 (9th Cir. 1947).

76 See TVT Records v. Island Def Jam Music Grp., 250 F. Supp. 2d 341, 349 (S.D.N.Y. 2003); Terry v. Masterpiece Advert. Design, No. 17 Civ. 8240 (NRB), 2018 WL 3104091, at *4 (S.D.N.Y. June 21, 2018).
} 
DeMO2 (Do Not DeleTE) 1 1/12/2021 5:42 AM

Consequently, while overreaching or speculative claims are rejected, as several cases highlighted, courts do allow a certain flexibility in the account of victim's losses. ${ }^{77}$

Lost profits based, for instance, on diverted-sales, theoretically, can be easily calculated, by multiplying the number of infringing items with their retail value. However, to reach an acceptable figure, reflecting the lost profits, there is a need to determine the profit margin for each sale, as well as the total number of lost sales. ${ }^{78}$ Nonetheless, as stressed in United States v. Beydoun, infringing items intended to, yet never sold (the "intended loss"), cannot be included in the calculation of lost profits. ${ }^{79}$ Moreover, there is no basis to assume that "every illegal download resulted in a lost sale." 80

Lost profits can also include licensing revenues from other parties, for example, for the use of the work in advertising, soundtracks, or television programs ("ancillary income"). ${ }^{81}$ To determine this type of income, plaintiffs can rely on "percentage multipliers of the overall sales projections," an "industry standard[ ]." 82

Infringers are only liable for actual profits, not for "potential" or "possible" profits. ${ }^{83}$ In Polar Bear $v$. Timex, for example, related to the defendant's infringement of film footage, the plaintiff was awarded $\$ 2.1$ million in indirect profits. The plaintiff's theory was that they could have sold at least more copies of the film if they would have had more financial resources. ${ }^{84}$ Notwithstanding, the Court of Appeals for the Ninth Circuit held that such claims must be demonstrated, not "dreamed," and considered that, in the case, the plaintiff's financial losses cannot be attributed to the defendant, as "mere speculation does not suffice to link the losses to the infringement," and remanded the award for remission of the excess. ${ }^{85}$

Elaborated methodologies for the calculation of lost profits can be found in a case brought to the High Court of the Republic of Singapore. ${ }^{86}$ In the case, the plaintiff claimed the amount of $\$ \$ 330,471$ as loss of profit, based on a threestep calculation: the total number of sign-ups, the percentage of clients who learn about the plaintiff through "online means", and the average contract price of sign-ups for the period. ${ }^{87}$ The loss of profit was then calculated by applying a

77 United States v. Anderson, 741 F.3d 938, 954 (9th Cir. 2013).

78 United States v. Fair, 699 F.3d 508, 514 (D.C. Cir. 2012).

79 United States v. Beydoun, 469 F.3d 102, 108 (5th Cir. 2006).

80 United States v. Dove, 585 F. Supp. 2d 865, 873 (W.D. Va. 2008).

81 TVT Records, 250 F. Supp. 2d at 349.

82 Id. at 349.

83 Peter S. Menell, Mark A. Lemley \& Robert P. Merges, Intellectual Property in the New Technological Age: 2018 (2018) at 836.

84 Polar Bear Prods. v. Timex Corp., 384 F.3d 700 (9th Cir. 2004).

85 Id. at 710.

86 Cordlife Grp. Ltd. v Cryoviva Singapore Pte Ltd. [2016] SGHCR 5 (Sing.).

87 Id. at 30 . 
formula which multiplies a number of elements: the total number of sign-ups; the decrease in growth rate; the percentage of clients who learned online about the plaintiff's business; the average contract price; and the average profit margin. 88

The Court, nevertheless, questioned the plaintiff's figures, such as the projected yearly growth rate, and held the methodology proposed by the plaintiff, implicitly the resulting figures, as "unsafe." 89 Instead, the Court proposed an alternative methodology, deriving plaintiff's sign-ups for the period as a percentage of the total number of childbirths in Singapore that year, and applying plaintiff's average contract price and profit margin, which, even accepting the percentage advanced by the plaintiff, regarding the potential Internet-based customers who were diverted away, gave a loss of expected profit of $S \$ 110,041 .{ }^{90}$ Concerning whether the decrease in the number of customers visiting plaintiff's website is attributable to the infringements in the case or to mere lawful competition, the Court held that the latter is the more plausible. ${ }^{91}$ Further, the Court also held that the copied text on the defendant's website "would not give any reasonable customer a reasonable basis to think that the Defendant is associated with the Plaintiff." 92

\section{Royalties}

Royalties are payments made to the copyright owner for the right to use certain works, for a period of time. As applicable, several approaches can be used to determine reasonable royalties as actual damages in cases of copyright infringement.

The main methods are the established royalty, the lost profits analysis, and the "fair market value" analysis. The latter involves the calculation of a "hypothetical license," which can be based on three approaches: the market approach (based on the examination of similar licenses, within a sector or an industry, on a "like-kind" basis); the income approach (based on anticipated uses of the work in the case); and the cost approach (based on the cost deemed necessary to develop an alternative technology or to replace the technology in the case). ${ }^{93}$

In a number of cases, courts have found that the only monetary recovery for the infringement is the award of a "hypothetical royalty". 94 Such royalty could represent the amount that the copyright owner would have received from a

$88 I d$. at 32

89 Id. at 36.

90 Id. at 37.

91 Id. at 49 .

92 Id. at 61,70

93 Oracle Corp. v. SAP AG, 734 F. Supp. 2d 956, 971 (2010).

94 Nimmer, supra note 14. 
DeMO2 (Do Not DeleTE) 1 1/12/2021 5:42 AM

willing licensee, for the same use involved in the infringement, when the infringement began. In other words, the "injury" is construed to be the lost licensing fee, which the defendant should have paid. ${ }^{95}$ This award, criticized by one of the foremost copyright law experts, ${ }^{96}$ actually makes the infringers mandatory licensees.

The calculation of damages based on royalties provides interesting arguments. For example, the issues raised by the determination of royalty as the fair market value, for hypothetical licensing, is very well illustrated by Oracle Corp. v. SAP. ${ }^{97}$ In the case, based on projected benefits and costs, the award was $\$ 1.3$ billion; the Court, nonetheless, considered the award speculative, as Oracle lacked a "history of granting [comparable] licenses" and presented no "evidence of 'benchmark' licenses in the industry approximating the hypothetical license in question." 98 The Court explained that, even though plaintiffs do not need to "demonstrate that it would have reached a licensing agreement with the infringer or present evidence of 'benchmark' agreements in order to recover hypothetical-license damages," it would be "difficult for a plaintiff to establish the amount of such damages without undue speculation in the absence of such evidence." $" 99$

It can be safely assumed that infringed works have a certain value. Plaintiff's estimates or beliefs regarding the fair market value of work, or what the percentage royalties should be of defendant's net sales, can be encountered in a number of cases. Such estimates, however, can be subjective, and held as not convincing enough for the award of the requested damages. An illustration of this situation can be found in Bachner v. US A Halloween Planet, where, even though the plaintiff argued that he was entitled to receive "up to $\$ 1,500$ " for the use of the infringed work, the Court held that, without evidence that would show the amount the plaintiff has received for the licensing of the photograph, or some evidence regarding the fair market value of the photograph, damages cannot be awarded on the claim. ${ }^{100}$ Similarly in Sullivan v. Flora, the failure to provide at least one example of royalties paid as a percentage of sales for advertising indirectly affecting the sales of a non-infringing product allowed no ground for the Court to award damages. 101

In On Davis v. The Gap, for another example relating to the unauthorized use of a photograph in an advertisement, the plaintiff requested, among other claims,

95 Mark A. Lemley, Should a Licensing Market Require Licensing?, 70 LAW \& CONTEMP. PROBS. 185, 195 (2007).

96 See Nimmer, supra note 14.

97 Oracle Corp. v. SAP AG, 765 F.3d 1081, 1088 (9th Cir. 2014).

98 Id. at 1093.

99 Id.

100 Bachner v. USA Halloween Planet, Inc., Cause No. 1:19-CV-64-HAB, 2020 WL 1862191 (N.D. Ind. Apr. 13, 2020).

101 Sullivan v. Flora, Inc., No. 15-cv-298-wmc, 2017 WL 1399464 (W.D. Wis. Apr. 25, 2017). 
$\$ 2,500,000$ in unpaid licensing fees. ${ }^{102}$ While the District Court held the claim as too speculative, the Court of Appeals for the Second Circuit, based on what the plaintiff received from a magazine as royalty for a photo, held that the jury should have established a "fair market value of at least $\$ 50$ " as fee for the use of plaintiff's copyrighted design. ${ }^{103}$ The Court of Appeals went on to hold that the dismissal of the claim based on the plaintiff's failure to prove economic harm would let the defendant "get his illegal taking for free, and the owner will be left uncompensated for the illegal taking of something of value."104 The Court also considered that "the fair market value of a reasonable license fee may involve some uncertainty," however, that was deemed as "not sufficient reason to refuse to consider this as an eligible measure of actual damages," and the case remanded for further proceedings. ${ }^{105}$

An important analysis in these cases regards the determination of the amount a willing buyer would pay to the copyright owner for the use of the work. ${ }^{106}$ In Polar Bear Productions, Inc. v. Timex Corp., for illustration, the Court held that license price advanced in the case reflects the amount the plaintiff actually quoted to the defendant, not an artificial, or inflated figure; consequently, the defendant "is in no better position to haggle over the license fee than an ordinary thief and must accept the jury's valuation unless it exceeds the range of the reasonable market value."107 In Thornton v. J Jargon Co., on the other hand, the Court underlined that the plaintiff failed to demonstrate the licensing of the work for fees, the fair market value of the work, or any evidence of "benchmark licenses," and held that there was no entitlement to a retroactive licensing fee. ${ }^{108}$

The calculation of the hypothetical license fee is heavily dependent on the licensing model adopted. ${ }^{109}$ In D'Pergo Custom Guitars, Inc. v. Sweetwater Sound, Inc., 110 for instance, the plaintiff's expert opted for a "rights managed" licensing model, where "usage fees are based not on file size, but upon the scope of usage

\footnotetext{
102 On Davis v. Gap, Inc., 246 F.3d 152, 156 (2d Cir. 2001).

103 Id. at 161.

104 Id. at 164.

105 Id. at 166.

106 See, e.g., Bell v. Taylor, 827 F.3d 699 (7th Cir. 2016) (explaining to prove the fair market
} value, the plaintiff used the licensing fee the defendants "should have paid" for legitimate use of the infringed work).

107 Polar Bear Prods., Inc. v. Timex Corp., 384 F.3d 700, 709 (9th Cir. 2004).

108 Thornton v. J Jargon Co., 580 F. Supp. 2d 1261, 1277 (M.D. Fla. 2008).

109 See, e.g., Epic Systems Corp. v. Attachmate Corp., No. 15-cv-179-bbc (W.D. Wis. June 21,2016 ) (showing the defendant cited the concurrent licensing model, valid for the use of the product in the case); Artifex Software, Inc. v. Hancom, Inc., No. 16-cv-06982-JSC (N.D. Cal. Sept. 12, 2017) (underlining the difference between the use of a commercial license as a way of valuing Defendant's breach of the GNU General Public License and the imposing of the terms of a commercial license on the defendant).

110 D’Pergo Custom Guitars, Inc. v. Sweetwater Sound, Inc., No. 17-CV-747-LM, 2020 WL 60351 (D.N.H. Jan. 6, 2020) (citing Doc. no. 116-2 at 13). 
DeMO2 (Do Not DeleTE) 1 1/12/2021 5:42 AM

desired by the client." The expert also used a competitive use multiplier, to include the "scenario in which an image licensor is approached by a direct competitor seeking to purchase licenses to make competing use of the licensor's photographs." 111

A number of cases brought to Italian courts, involving the infringement of copyright-protected works of Reti Televisive Italiane (RTI), provide interesting calculations of the hypothetical license fee. The award is determined by quantifying the reasonable fee, which can be found in the market, for the specific type of use of the infringed work. In RTI $v$. Dailymotion, ${ }^{112}$ for instance, which involved the infringement of at least 995 videos, the Court calculated the amount of royalties by considering the price for a hypothetical license that the platform would need, in order to lawfully display the protected content, the so-called "price of consent" (prezzo del consenso, about $€ 700 /$ minute), and multiplied by the number of minutes illegally transmitted (7556, calculated from when the video was uploaded on the platform, until the time of removal), resulting in an award of $€ 5.521 .420$. In RTI v. Facebook, the Court ascertained the value of the royalties for the use of the audiovisual pieces infringed by taking into consideration the length of the time the work was accessible online (about two years), the duration of each video (five minutes), and, based on the reference to three contracts, considered comparable, for which the Court averaged the fees, a fee of $€ 809.50$ per minute of use, as the amount envisaged for the annual licenses. ${ }^{113}$

In RTI v. Megavideo, which involved the illegal streaming of TV programs, the Court carefully evaluated the damages using as parameter the price of consent, determined based on the royalties applied by the plaintiff to license the use of content, and the amount of money a user would have had to pay, for the time and according to the methods of use of the programs. ${ }^{114}$ The market analysis was carried out on products not directly comparable with the programs in the case but was relevant to the case in question, and damages were quantified by averaging the different values of the agreements examined. ${ }^{115}$

To ascertain the actual damages, plaintiffs sometimes use multipliers, quality factors, and the loss of exclusivity. A "scarcity multiplier" is used to "compensate for a work's loss in value based on the decreased likelihood that potential buyers will purchase a work that has been displayed commonly and widely on the internet to advertise outdoor destinations and products." 116 In a

111 Id. (citing Doc. no. 116-2 at 27).

112 Tribunale di Roma, sez. XVII, 12 luglio 2019, sentenza n. 14757 (R.G. 24711/2012).

113 Tribunale di Roma, sez. XVII civile, 15 febbraio 2019, sentenza n. 3512 (R.G. 33124/2012).

114 Tribunale Civile di Roma, sez. nona, 7 luglio 2016, sentenza n. 6515.

115 Id.

116 Cate Brown Photography v. David-Jacobs Publ'g Grp., LLC, No. 8:19-cv-447-T02CPT, at *2 (M.D. Fla. Aug. 27, 2019). 
case that involved the unauthorized use of a photograph of a sailboat, infringed by the defendant as part of his online sale of goods, the plaintiff claimed actual damages totaling $\$ 6,720$, based on the price of a single use license fee per year, multiplied by a scarcity factor and a quality factor of four. ${ }^{117}$ The court, however, found that three times the actual damages was appropriate in the case. ${ }^{118}$

In Leonard v. Stemtech, ${ }^{119}$ the determination of the fair market value of a license involved an even more sophisticated methodology, comprising quotes from stock photo agencies, for the various forms of media used to infringe the work in the case, which led to a "benchmark licensing fee," then the average of the fees was applied to the number of infringing uses identified in the case. ${ }^{120}$ The figure was further upward adjusted to "account for the 'scarcity or rarity' of images," adjusted for "exclusivity," to account for "overuse or broad use", by "adding a premium of 3.75 to 8.75 times the benchmark." 121 The final amount calculated by the expert in this case was in the "range from $\$ 1.4$ million to nearly $\$ 3$ million," the jury returning an award of $\$ 1.6$ million. ${ }^{122}$

This type of award, according to the circumstances presented in each case, can be the result of multiplying the amount of the licensing fee by certain numbers, as a way "to ensure that the cost of violating the copyright laws is substantially greater than the cost of complying with them."123

Depending on the species of protected work, the assessment of royalties payable can be further compounded by the existence of various types of royalties ${ }^{124}$ and the actual number of infringing copies. The latter often raises practical problems, due to a number of factors. For instance, interpretation issues (even when the terms that define the infringement, for instance, "reproduction," "distribution," "public performance," or "communication,"125 are defined in the national laws, as they comprise a large array of conduct, ${ }^{126}$ they

117 Id.

118 Id.

119 Leonard v. Stemtech Intern. Inc., 834 F.3d 376 (3d Cir. 2016).

120 Id. at 385.

121 Id. at 385.

122 Id. at 385.

123 Joe Hand Promotions, Inc. v. Aguilar, No. 5:18-CV-1935-LCB, 2020 WL 836844 (N.D. Ala. Feb. 20, 2020) at *6.

124 For musical works, for instance, there are mechanical royalties (i.e., for sales of discs, etc.); synchronization royalties (for music synchronized with visual images); song book and folio royalties (for the sale of printed music; and public performance royalties (for public performances of musical works, such as live performances), see Brown v. Goldstein, 34 Cal. App. 5th 418, 421 (Cal. Ct. App. 2019).

125 Regarding definitions of "reproduction" and "distribution," see the Italian Copyright Law (Art. 13 and 17); regarding "communicate", see Singapore Copyright Law, 7(1).

126 For instance, "distribution," see Peter S. Menell, In Search of Copyright's Lost Ark: Interpreting the Right to Distribute in the Internet Age, 59 J. CopyrigHT SOC'Y U.S.A. 1 (2011). For "reproduction," see Harmony Consulting Ltd. v. G.A. Foss Transportation Ltd., 2011 F.C. 340 
DeMO2 (Do Not DeleTE) 1 1/12/2021 5:42 AM

can be interpreted in multiple ways), and to the characteristics of the digital medium (e.g., the case of software installed on a server, accessible via remote computers).

These determinations, however, are very important, as they directly affect the amount of the awards received. In Seoul Broadcasting v. Sang, for an illustration, the plaintiffs asserted that there were 1,440 infringements, a figure derived from defendant's admission that he copied, rented, or sold twenty DVDs, containing two protected programs per week, over several months, and asked the Court to award $\$ 30,000$ per infringement. ${ }^{127}$ The Court, nevertheless, held that "such admissions do not lead to the conclusion that 1,440 copyrights were infringed," instead that just establishes that the defendant made 1,440 unauthorized copies or sales of protected works, generally, without demonstrating how many works were infringed. ${ }^{128}$

\section{DISGORGEMENT OF PROFITS}

The disgorgement of infringers' profits, a form of addressing "unjust enrichment," aims to take the ill-gotten gains from the defendants, and to deprive them of the gains or benefits obtained from the infringing acts, not taken into account in the calculation of the actual damages. Nonetheless, it can be debated whether actual damages and profits can be allowed alternatively or cumulatively, or what would be the degree of exclusiveness between the two. In this context, it is important to note a statement from the Italian Supreme Court, according to which the objective of this award is to prevent illegal users from obtaining advantage from the unauthorized conduct, by withholding the profits obtained, in the place of the owner of the legitimate right of appropriation. ${ }^{129}$

In the context of this award, the wrongful, unfair, or ill-gained profits made by the infringers, justly attributable to the infringement in the case, should be understood as revenues minus expenses (that is, defendant's net gains, based on the infringement, not the plaintiff's losses). This award supplements, and does not duplicate, the actual damages. This important distinction came under

(Can.). For "communicate," see Total English Learning Global Pte Ltd. \& anor v. Kids Counsel Pte Ltd. [2013] SGHCR 22 (Sing.) (holding that the term "communicate" and the phrase "to communicate the work to the public" are limited to communication via electronic transmission) (emphasis added). For "public performance", see United States v. American Society of Composers, Authors, \& Publishers, 485 F. Supp. 2d 438, 442 (S.D.N.Y. 2007) (holding that "the streaming of a musical work does constitute a public performance, we conclude that the downloading of a digital music file, in and of itself, does not."). See also Wnet, Thirteen v. Aereo, Inc., 712 F.3d 676 (2d Cir. 2013); American Broad. v. Aereo, Inc., 134 S. Ct. 2498, 573 U.S. 431 (2014).

127 Seoul Broad. Sys. Int'l, Inc. v. John Kim Sang, 754 F. Supp. 2d 562, 566 (E.D.N.Y. 2010).

128 Id. at 568.

129 Paolo Pardolesi, 134 Il Foro Italiano, 3067, sentenza n. 8730 (2011). 
scrutiny in McRoberts Software, Inc. v. Media 100,130 where, as damages for the infringement of a computer program, the jury awarded the plaintiff $\$ 1.2$ million in actual damages and $\$ 900,000$ in lost profits. On appeal, the defendant claimed that the damages awarded were unsupported by evidence and the lost profits award duplicates the actual damages award. ${ }^{131}$

While the defendant argued that it realized no profits from sales of products that incorporated the copyrighted program, the plaintiff presented evidence that, as a result of defendant's copyright infringement, it suffered damages between $\$ 1.43$ and $\$ 15.6$ million. ${ }^{132}$ In this case, the jury received unequivocal instructions, to avoid the inclusion of amounts already considered in the determination of the actual damages: actual damages represent "the amount a willing buyer would have been reasonably required to pay a willing seller at the time of the infringement for the use made by Media 100," while defendant's profits represent "the amount of money that Media 100 made because of the infringement minus deductions for expenses in producing and marketing the infringing work."133 As the evidence of plaintiff's injuries was "more than adequate to support the jury's total damage award," the Court held that the award for lost profits cannot be considered duplicative of the award for actual damages. 134

The disgorgement of the net ill-gotten profits aims to eliminate the incentive to infringe, instead of paying the right proprietor for the use of works. In other words, as the Court of Appeals for the Fourth Circuit noted:

awarding only the plaintiff's injury, would allow for cases of 'efficient infringement,' i.e., situations where the profit exceeded the licensing fee, leaving infringers indifferent as to whether they paid up front or paid in court ... stripping the infringer not only of the licensing fee but also of the profit generated as a result of the use of the infringed item, the law makes clear that there is no gain to be made from taking someone else's intellectual property without their consent. ${ }^{135}$

Whether and what profits the copyright owner would have made through the exploitation of the work in the case is irrelevant for determining the applicability of this compensation criterion. In Paragon v. Lee, for illustration, a case which involved the misuse of plaintiff's copyrighted materials, the Supreme Court of

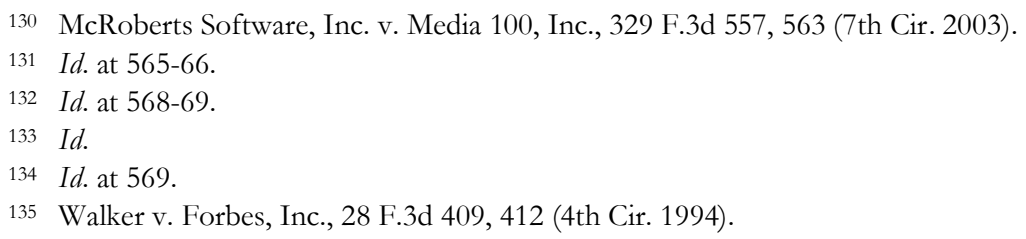


DeMO2 (Do Not DeleTE) 1 1/12/2021 5:42 AM

British Columbia held that the plaintiff is entitled to the disgorgement of profits, calculated based on the reasonable estimates of amounts charged by the defendant for average purchases each month, from online course, class instruction, and sale of textbooks. ${ }^{136}$

The quantification of the ill-gained profits is often a difficult analysis. The United States Code, for instance, explicitly requires the copyright owner "to present proof only of the infringer's gross revenue," while the infringer is "required to prove his or her deductible expenses and the elements of profit attributable to factors other than the copyrighted work." 137 These requirements allow for interesting arguments, concerning both the gross revenue and the defendant's expenses, which can be considered deductible in accounting for the ill-gotten profits, particularly as infringers are required to prove the deductible expenses with specificity.

The award of this remedy further requires the plaintiff to demonstrate the "causal connection" between the infringement and the profits derived by the defendant. 138 In Sullivan v. Flora, for example, the Court held that a "general indication" of value cannot be accepted as "evidence supporting a causal nexus between the infringing use and defendant's revenues," and, since, in the case, the plaintiff has not presented evidence that would demonstrate that the infringed illustrations attracted more customers or increased the sales of the defendant's products, there was no basis for awarding defendant's profits. ${ }^{139}$ The requirement to demonstrate the gross revenue implies that the plaintiff must apportion the revenue linked to the infringing activity from the defendant's other revenues. The apportionment of profits can be done by employing various analytic methods or formulas, however, it usually is not an easy task, and it was scrutinized by courts in several cases. Nonetheless, as the Court of Appeals of the Ninth Circuit held, if "a reasonable, nonspeculative formula cannot be derived, or that the amount of profits a reasonable formula yields is insufficient to serve the purposes underlying the statute, then the court should award statutory damages." 140

In On Davis v. The Gap, for instance, the plaintiff, following the unauthorized use by the defendant, in an advertisement for Gap stores, of a photograph, showing an individual wearing his copyrighted eyewear, requested a percentage of Gap's profits. ${ }^{141}$ The plaintiff, however, "failed to show any causal connection

136 Paragon Testing Enters. Inc. v. Lee, 2018 BCSC 634, para. 36-8 (Can.).

13717 U.S.C. 504(b).

138 See SEC v. Thomas James Assocs., Inc., 738 F. Supp. 88, 94 (W.D.N.Y. 1990); Polar

Bear Prods., Inc. v. Timex Corp., 384 F.3d 700, 714 (9th Cir. 2004).

139 Sullivan v. Flora, Inc., No. 15-cv-298-wmc (W.D. Wis. Apr. 25, 2017).

140 Frank Music Corp. v. Metro-Goldwyn-Mayer, Inc., 772 F.2d 505, 519 (9th Cir. 1985).

141 On Davis v. The Gap, Inc., 246 F.3d 152, 156 (2d Cir. 2001). 
between the infringement and the defendant's profits." 142 The Court admitted that "a highly literal interpretation of the statute would favor Davis," however, it considered that the term "gross revenue" should be understood as "gross revenue reasonably related to the infringement, not unrelated revenues," and denied plaintiff's claim for infringer's profits. ${ }^{143}$

Among the most disputed deductible items are taxes paid and overhead expenses. ${ }^{144}$ Where courts do not receive evidence of deductible expenses, or reject defendant's attempt to prove such expenses, the award amounts to the full amount of revenue. ${ }^{145}$ In Cadence Design Systems v. Pounce Consulting, for illustration, the defendant used without legal right plaintiff's software to design schematics. ${ }^{146}$ The plaintiff's royalty auditor calculated that the defendant derived a total revenue of about $\$ 3$ million from the use of the protected computer program in providing services to its customers. ${ }^{147}$ The court held that there was no evidence that would reduce the gross revenue to a sum more representative of the actual profits received and, taking into account that the defendant had an annual revenue of about $\$ 70$ million, found the award of about $\$ 3$ million for the infringement claim appropriate. ${ }^{148}$

In Frank Music v. Metro-Goldwyn-Mayer, for another example, the dispute concerned the unauthorized use of five songs in a musical revue. ${ }^{149}$ The District Court found that the gross revenue MGM earned from the presentation of the musical revue was $\$ 24,191,690$, with direct costs of $\$ 18,060,084$ and indirect costs of $\$ 3,641,960.150$ The plaintiffs argued that the District Court erred by allowing deductions for overhead expenses, as the defendants did not prove that each claimed item assisted in the production of the revue, and by not including in the gross profits calculation the defendant's earnings from the hotel and gaming operations. ${ }^{151}$ The Court of Appeals agreed it was unclear how the costs claimed by the defendant contributed to the production of the musical revue, ${ }^{152}$ and pointed out that when the profits of the infringer can also be attributed to

142 Id. at 159.

143 Id. at 160.

144 See Kenneth E. Burdon, Note, Accounting for Profits in a Copyright Infringement Action: A Restitutionary Perspective, 87 B.U. L. Rev. 255, 262 (2007); Design Basics, LLC v. Petros Homes, Inc., No. 1:14-CV-01966 (N.D. Ohio Mar. 7, 2017).

145 Singletary Constr., LLC v. Reda Home Builders, Inc., No. 19-5491 (6th Cir. June 1, 2020).

146 Cadence Design Sys., Inc. v. Pounce Consulting, Inc., No. 17-cv-04732-PJH (SK) (N.D. Cal. Apr. 22, 2019).

147 Id.

148 Id.

149 Frank Music Corp. v. Metro-Goldwyn-Mayer, Inc., 772 F.2d 505, 509-10 (9th Cir. 1985).

$150 \quad I d$. at 515.

151 Id.

152 Id. at 516. 
DeMO2 (Do Not DeleTE) 1 1/12/2021 5:42 AM

other factors than the use of the plaintiff's work, an apportionment must be made. ${ }^{153}$

The Court of Appeals for the Ninth Circuit held that the adequate apportionment method and the determination of the award amount is "largely a factual exercise."154 The Court judged that direct profits, from the show itself as well as indirect profits, derived from hotel and gaming operations, if ascertainable, are recoverable. Consequently, the Court vacated the District Court's award of $\$ 22,000$ in apportioned profits as "grossly inadequate" and remanded to the District Court for reconsideration. ${ }^{155}$

This form of compensatory award can, and sometimes does, render plaintiffs receiving damages that exceed significantly their losses. ${ }^{156}$ In GC2 v. International Game Technology, for instance, the jury awarded modest actual damages, however, it also found that $75 \%$ of each of the defendants' relevant profits can be attributed to the infringed works. ${ }^{157}$ In the case of one of the defendants, for example, the actual damages awarded were $\$ 536,677$, while the disgorged profits were $\$ 3,585,787.81 .158$

\section{STATUTORY DAMAGES}

\section{Preliminary Observations}

The legislation of all WIPO member states allows for the compensation of actual harm linked to infringements, and many states provide for the disgorgement of defendant's profits directly attributable to the infringement in the case. However, few countries have enacted legal provisions for the award of statutory damage in cases of copyright infringement. ${ }^{159}$ Statutory damages are available, among the jurisdictions under consideration in this article, in the U.S., Canada, and Singapore, when elected by the aggrieved party.

Leading legal commentators consider these awards "controversial," 160 raise questions regarding their application in certain cases, ${ }^{161}$ and point to their potential to turn statutory damages litigations "into a game of financial Russian roulette,"

153 Id. at 518.

$154 \quad I d$. at 518

155 Id.

156 Ewoud Hondius and André Janssen, Disgorgement of Profits: Gain-Based Remedies throughout the World 475 (E. Hondius \& A. Janssen eds., Springer 2015).

157 GC2 Inc. v. Int'l Game Tech., 391 F. Supp. 3d 828, 838 (N.D. Ill. 2019).

158 Id.

159 Samuelson, Hill \& Wheatland, supra note 14, at 531.

160 Depoorter, supra note 14, at 404-6.

161 See Mark A. Lemley, Should a Licensing Market Require Licensing?, 70 LAW \& CONTEMP. PROBS., 185, 197 (2007) (observing that statutory damages "can far exceed either the copyright owner's loss or the defendant's gain."); Peter S. Menell, This American Copyright Life: Reflections on Re-equilibrating Copyright for the Internet Age, 61 J. COPYRIGHT SOC'Y U.S.A. 235 (2014). 
or to allow for "exploitative litigation business models."162 Statutory damages, nevertheless, represent a viable alternative remedy to, and mutually exclusive from, the compensatory remedies of actual damages and the additional profits obtained by the defendant from the infringing acts. ${ }^{163}$

This election is allowed because actual damages and profits made by the defendant are "often conjectural, and may be impossible or prohibitively expensive to prove." 164 According to Professor Depoorter, plaintiffs actually request statutory damages in 90 percent of the U.S. cases. ${ }^{165}$ In Cable/Home Communication v. Network Productions, for example, the election of statutory damages was due to the plaintiff's inability to get information on the defendants' profits. ${ }^{166}$ Similarly, in Walt Disney $v$. Powell the District Court found that the defendant "did not keep normal business records," which made the determination of the profits made from infringements impossible. ${ }^{167}$

Statutory provisions ease the damage evidentiary requirement for the owner of the work infringed. As noted in one case, "Congress labeled these damages as 'statutory' rather than 'punitive' which suggests that they are not solely awarded for the sake of punishment, but also as compensation for unproven harm."'168 Therefore, the award of statutory damages is not contingent on the demonstration of actual damages. ${ }^{169}$ In Adobe Systems Inc. v. Software Tech, for instance, the plaintiff failed to present evidence of lost profits and was not able to obtain defendants' sales figures, thus inhibiting the calculation of infringer's profits. There the court held it was appropriate to award statutory damages. ${ }^{170}$

Statutory damages are designed to be mainly compensatory or restitutionary in nature, nonetheless; they are also used to discourage misconduct, ${ }^{171}$ amounting to effective "compensation and punishment" awards. ${ }^{172}$ Courts have wide discretion in assessing statutory damages. These awards are not intended to provide windfalls to plaintiffs. Courts decide what is appropriate in every

162 Mitch Stoltz, The Key To Fixing Copyright Is Ending Massive, Unpredictable Damages Awards, ELECTRONIC Frontier Foundation (Jan. 23, 2020), https://www.eff.org/ro/deeplinks/2020/01/key-fixing-copyright-ending-massiveunpredictable-damages-awards.

16317 U.S.C. $\$ 504(\mathrm{c})(1)$.

164 Sony BMG Music Ent. v. Tenenbaum, 721 F. Supp. 2d 85, 103 (D. Mass. 2010).

165 Depoorter, supra note 14, at 407.

166 Cable/Home Commc'n Corp. v. Network Prods., 902 F.2d 829, 840 (11th Cir. 1990).

167 Walt Disney Co. v. Powell, 897 F.2d 565, 567 (D.C. Cir. 1990).

168 In re Braun, 327 B.R. 447, 450 (Bankr. N.D. Cal. 2005).

169 Sony BMG Music Ent. v. Tenenbaum, 660 F.3d 487, 507 (1st Cir. 2011).

170 Adobe Sys. Inc. v. Software Tech, No. 5:14-cv-02140-RMW (N.D. Cal. Nov. 10, 2015).

171 Lived In Images, Inc. v. Noble Paint and Trim, Inc., No. 6:15-cv-1221-Orl-40DAB (M.D. Fla. Feb. 5, 2016) ("to discourage wrongful conduct"); Cable/Home Communication Corp., 902 F.2d at 852 ("court should consider both the willfulness of the defendant's conduct and the deterrent value of the sanction imposed.").

172 Feltner v. Columbia Pictures Television, Inc., 523 U.S. 340, 352 (1998). 


DeMO2 (Do Not DeleTE) 1 1/12/2021 5:42 AM

particular case, "considering the nature of the copyright, the circumstances of the infringement and the like...."173

\section{Amount of the Award}

The amount of statutory damages awards is a jury determination, evaluated, in each case, following applicable statutory provisions and case law. The factors considered in the award of statutory damages include: the nature of the infringement; the defendant's purpose and state of mind; the profits obtained by that the defendant; the revenue lost by the copyright owner as a result of the infringement; the value of the work infringed; the duration of the infringement. ${ }^{174}$ Other factors include: the continuation of the infringement after notice; the need to deter similar infringing acts; infringer's attitude and cooperation in the court proceedings. ${ }^{175}$

Statutory damages can serve two important purposes: compensate the plaintiff and punish the defendant. The tribunal can award statutory damages even when the defendant's scheme failed. ${ }^{176}$ There should be, nonetheless, a "correlation," or "proportionality," between actual damages and the statutory damages awarded. ${ }^{177}$

An exemplary analysis, which followed the principle of proportionality, can be found in a case brought to the San Jose Division. ${ }^{178}$ The case concerned 17,146 unauthorized activation of the plaintiff's computer program, with an estimated total value of $\$ 14,842,254 .{ }^{179}$ Nonetheless, the Court stressed that the number of separate products activated without authorization was nineteen, and further held questionable to assume that, absent the infringements, the plaintiff would have made additional sales for each infringement. ${ }^{180}$ Moreover, that Court noted that, even if all the infringements would have resulted in a sale, the amount would represent "gross revenue," not lost profits. ${ }^{181}$ Consequently, the Court awarded $\$ 100,000$ per infringed work ( $\$ 1,900,000$ in total). ${ }^{182}$

Instructive illustrations of the application of the "direct correlation" principle

173 Peer Int'l Corp. v. Pausa Recs., Inc., 909 F.2d 1332, 1336 (9th Cir. 1990).

174 Bryant v. Media Rights Prods., Inc., 603 F.3d 135, 144 (2d Cir. 2010).

175 Id.

176 Zekelman Indus., Inc. v. Marker, No. CV-19-02109-PHX-DWL (D. Ariz. Mar. 26, 2020)

(noting that the defendants stole copyrighted videos and published them, in an attempt obtain $\$ 108,000$ of dealer fees).

177 Trader Corp. v. CarGurus Inc., [2017] ONSC 1841 (Can.).

178 Adobe Sys. Inc. v. Software Tech, No. 5:14-cv-02140-RMW (N.D. Cal. Nov. 10, 2015).

179 Id. at $* 5$.

$180 I d$. at $* 6$.

181 Id.

182 Id. 
can also be found in other cases. In Dermansky v. Telegraph Media, LLC, ${ }^{183}$ for instance, the defendant copied the plaintiff's photograph directly from another online article and removed the gutter credit. ${ }^{184}$ Plaintiff requested the award of the maximum statutory damages, without, however, presenting any evidence of lost revenue or other damages. ${ }^{185}$ The Court determined that the infringing conduct was de minimis and set the amount of statutory damages at $\$ 1,000$, considered sufficient to "account for the willful actions of Defendant and the need to deter others." 186 In Hirsch v. Sell It Social, LLC, ${ }^{187}$ the defendant, without license or permission, published a photo, owned by the plaintiff, on a commercial website. ${ }^{188}$ The Court, taking into consideration the "single instance" of the infringement and that the fee for licensing the photo could be construed as "de minimis," held that a damage award of $\$ 5,000$ would be adequate deterrence in the case. 189

The wide statutory range, however, permits substantial discretion in setting the awards, which allows for significant levels of inconsistency or disparity. ${ }^{190} \mathrm{~A}$ number of cases are instructive in this regard. In Malibu Media, LLC v. Doe, for instance, the defendant used BitTorrent to willfully infringe thirteen copyrighted movies. ${ }^{191}$ The plaintiff asked for statutory damages of $\$ 1,500$ per work. Even though the plaintiff's requested damages were at the "lower end of the statutory range," the court awarded just the minimum available, $\$ 750$ per work. ${ }^{192}$ In Broadcast Music, Inc. v. Tommy Doyles Hyannis, LLC, the plaintiffs had protected copyright interest in four songs, "publicly performed ... without license or permission." 193 The plaintiffs requested statutory damages in the amount of $\$ 6,000$ per work. The Court noted that "a fee of $\$ 3,011$ would have provided the [d]efendants the rights to play 8.5 million songs" for an entire year and instead awarded the statutory minimum award of $\$ 750$ per song infringed, holding that this will "adequately serve the purposes of deterring putative

183 Dermansky v. Tel. Media, LLC, No. 19-CV-1149 (PKC)(PK), 2020 WL 1233943 (E.D.N.Y. Mar. 13, 2020).

184 Id. at $* 5$.

185 Id. at $* 1$.

186 Id. at $* 6$.

187 Hirsch v. Sell It Soc., LLC, No. 20 CV 153-LTS-BCM, 2020 WL 5898816, (S.D.N.Y. Oct. 5, 2020).

$188 I d$. at $* 2$.

189 Id. at $* 12$.

190 See LHF Prods., Inc. v. Gonzales, No. 2:17-cv-00103-DN, 2020 WL 6323425 (D. Utah Oct. 28, 2020) (underlining the "limited analysis and disparity in awards that existed in many infringement cases involving use of BitTorrent protocols from 2012 through 2017.").

191 Malibu Media, LLC v. Doe, No. 18-cv-14037, 2020 WL 134112 (E.D. Mich. Jan. 13, 2020).

192 Id. at $* 8$.

193 Broad. Music, Inc. v. Tommy Doyles Hyannis, LLC, Civil Action No. 13-cv-12258-IT, 2015 WL 3649682, *2 (D. Mass. June 10, 2015). 
DeMO2 (Do Not DeleTE) 1 1/12/2021 5:42 AM

infringers." 194 In Bryant v. Media Right Productions, ${ }^{195}$ the Court of Appeals of the Second Circuit upheld the District Court decision to award $\$ 2,400$ in statutory damages, based on the findings that the profits from the infringing sales were meager and that "the award did not need to be higher to achieve deterrence, because deterrence was effectuated here by Appellees having to pay their own attorneys fees." 196

The use of multipliers to calculate awards based on the licensing fee also provides significant variations between courts. In the Orlando Division, for example, in a case where the plaintiff requested statutory damages of $\$ 50,000$, the Court, considering that the photograph in the case had a license value of $\$ 1,000$ to $\$ 1,500$, held that "a ten-fold multiple of that amount of $\$ 10,000$ is appropriate." 197 In the Tampa Division, on the other hand, the Court declined to apply the scarcity multiplier requested by the plaintiff. The plaintiff requested a scarcity multiplier of five and provided evidence that the yearly licensing fee to use the work in the case was $\$ 5,000$, with significant enhancements to the work and significant lost value due to its dissemination on the defendant's website. Instead, the court issued a judgment that the statutory damages should only be two times the licensing fee (resulting in an award of $\$ 10,000$ ). 198

In a Second Circuit case, the plaintiffs requested an award of $\$ 15,000$ per infringement, representing about six times the amount of the licensing fees. ${ }^{199}$ However, the Court held that, in that Circuit, the statutory awards commonly amount to "three and five times the cost of the licensing fees," and set the award at $\$ 12,500$ per infringement, about five times the amount of unpaid licensing fees. ${ }^{200}$

\section{Number of Works Infringed}

Statutory damage awards account for the number of works infringed, not the number of infringements. For example, according to the judgment of the Federal Court of Ontario in Young v. Thakur, the number of times a video is viewed on a website "does not multiply the works infringed."201 This approach, however, can be questioned in cases of massive infringement involving

194 Id. at $* 4$.

195 Bryant v. Media Right Prods., Inc., 603 F.3d 135, 138, 143 (2d Cir. 2010).

196 Id. at 144.

197 Lived In Images, Inc. v. Noble Paint and Trim, Inc., No. 6:15-cv-1221-Orl-40DAB, 2016 U.S. Dist. LEXIS 23801, *9, *13 (M.D. Fla. Feb. 5, 2016).

198 Crisman v. Intuition Salon and Spa, LLC, No. 8:19-cv-2963-T-24 AAS, 2020 WL 1492770 (M.D. Fla. Mar. 27, 2020).

199 Broad. Music, Inc. v. Prana Hosp., Inc., 158 F. Supp. 3d 184, 199 (S.D.N.Y. 2016).

200 Id. at 199.

201 Young v. Thakur, [2019] F.C. 835 at 44 (noting that the defendant viewed a video 82 times, yet the Court held that "number of views on the website does not multiply the works infringed.") (Can.). 
reproduction or distribution. For illustration, in Twentieth Century Fox Film Corp. v. Streeter, the plaintiff used an online media distribution system, "with tens of millions of potential users," to make available to the public motion pictures, ${ }^{202}$ yet the statutory damage award was $\$ 3,000$ per infringement, hardly serving the above stated "compensation and punishment" purpose.

The analysis of whether the defendants infringed "one work" or "multiple works" allows for interesting arguments. There are approaches according to which the "number of copyright registrations "is not determinative of the number of statutory damage awards," and analysis which regards whether the plaintiff issued the works "separately, or together as a unit." 203 If the plaintiff created a "collective work" and "compilation," they are limited to recovery of one award of statutory damages per set. ${ }^{204}$ However, such a determination is not always straightforward.

There is divided authority on what constitutes "compilation," or how a "compilation" is treated for the purpose of determining the number of awards. Some courts use the "registration" or "issuance" test, while others use the "separate economic value" or "functional" test. The determination, nevertheless, is essential, as it can limit the claimants to a single award, or it allows for multiple statutory awards (if any or all works are infringed).

In VHT v. Zillow Group, for example, the Court of Appeals for the Ninth Circuit, in a case involving thousands of copyrighted photos, had to determine if a photo database is a compilation, 205 and held that "there were at least ten different copyright registrations, thousands of photos, and no explicit determination on compilation," declined to "sort out the compilation issue on appeal," and remanded to the District Court for the determination on whether the photos at issue constitute a compilation. ${ }^{206}$ On remand, the plaintiff argued that the images are "separate works because they were separately infringed," while the defendant argued that the "images' independent economic value is 'irrelevant' to the compilation issue." 207 Based on an extensive analysis, comprising the review of relevant statutory provision, its prior analysis, and the Ninth Circuit's opinion on "compilation," followed by the reconciliation of Ninth Circuit's authorities, the District Court concluded that the images in the

202 Twentieth Century Fox Film Corp. v. Streeter, 438 F. Supp. 2d 1065, 1072-73 (D. Ariz. 2006).

203 Minden Pictures, Inc. v. Buzzfeed, Inc., 390 F. Supp. 3d 461, 469 (S.D.N.Y. 2019) (quoting ASA Music Prods. v. Thomsun Elecs., No. 96-CV-1872 (BDP)(MDF), 1998 WL 988195 at *8 (S.D.N.Y. Sept. 29, 1998) and Bryant v. Media Right Prods., Inc., 603 F.3d 135, 141 (2d Cir. 2010)).

204 Id.

20517 U.S.C. $\$ 101(2010)$.

206 VHT, Inc. v. Zillow Grp., Inc., 918 F.3d 723, 748 (9th Cir. 2019) (the jury concluded that the defendant directly infringed 28,125 photos).

207 VHT, Inc. v. Zillow Grp., Inc., 461 F. Supp. 3d 1025, 1040, 1041 (W.D. Wash. 2020). 
DeMO2 (Do Not DeleTE) 1 1/12/2021 5:42 AM

case do not constitute a "compilation."208

In Minden Pictures v. Burzfeed, the District Court of the Southern District of New York held that, a number of photographs, assembled into a collective whole, registered as "collective work," constitute a compilation, rather than individual photographic works, entitling the right owner to just one statutory damages award per set. ${ }^{209}$ A similar judgment can be found in Bryant $v$. Media Right Productions: the Court of Appeals for the Second Circuit declined to apply the "functional" test, and awarded just one statutory award per the infringement of two albums of music, not one award per each song, as the plaintiffs requested, as the albums were deemed "compilations," holding irrelevant that the songs included in the albums may have received a separate copyright. ${ }^{210}$

For illustration of the "functional" test, the Court of Appeals for the First Circuit held that the copyright proprietor can register multiple works on a single form, counting thus as "one" work for the purposes of registration, however, for the purpose of statutory damages, an award can be collected for each work. ${ }^{211}$ The "functional" approach, however, was not accepted by the Court of Appeals for the D.C. Circuit in Walt Disney Co. v. Powell. ${ }^{12}$ In the case, the defendant was selling shirts printed with characters that resembled Disney's Mickey and Minnie Mouse, and the District Court found six infringements, however, the judgment of the Appeal Court was that, while "Mickey and Minnie are certainly distinct," with independent "economic value and copyright lives of their own," nevertheless "Mickey is still Mickey whether he is smiling or frowning, running or walking, waving his left hand or his right."213 Consequently, the Appeal Court, as it found that the defendant infringed only two works, held that the District Court erred in awarding damages on six infringements. ${ }^{214}$

\section{Enhanced Awards}

Statutory damage awards can be enhanced on the basis of "willful" infringement or high losses sustained by the plaintiffs. The term "willfulness" is not defined by the USCA, therefore, to prove this element, courts usually require the plaintiff demonstrate "that the defendant was actually aware of the infringing activity," or "that the defendant's actions were the result of 'reckless disregard' for, or 'willful blindness' to, the copyright holder's rights." 215 Higher statutory

208 Id. at 1041-44.

209 Minden Pictures, 390 F. Supp. at 469.

210 Bryant v. Media Right Prods., Inc., 603 F.3d 135, 142 (2d Cir. 2010).

211 Gamma Audio \& Video, Inc. v. Ean-Chea, 11 F.3d 1106, 1116-1117 (1st Cir. 1993).

212 Walt Disney Co. v. Powell, 897 F.2d 565 (D.C. Cir. 1990).

213 Id. at 570.

214 Id.

215 Island Software \& Comput. Serv., Inc. v. Microsoft Corp., 413 F.3d 257, 263 (2d Cir. 2005). 
awards are granted only in "exceptional cases," where there is "evidence of especially egregious circumstances;" for instance where the defendant "is a counterfeiter, a chronic copyright infringer, or if, after receiving notice of Plaintiff's claims, takes no action to investigate and merely continues its' infringing behavior."'216

In order to demonstrate a high level of "willfulness," numerous factors can be cited, allowing for the application of enhanced damages (under 17 U.S.C. $\$$ 504(c) (2), up to $\$ 150,000)$ : defendant's refusal to comply with "cease and desist" letters; ${ }^{217}$ defendant's failure to respond to the summons, complaints, default judgment motions; the removal of the accreditation for the work; ${ }^{218}$ etc. In Epic Tech v. Lara, ${ }^{219}$ for instance, the Court, taking into account the willfulness of the defendants' conduct; the deterrent effect of the award; the value of the copyrights the non-cooperation of the defendants in providing the required records; and the losses incurred by the plaintiff ( $\$ 15$ million of total losses), set the damage award at $\$ 150,000$ for each of six copyright infringements.

Several cases had a long and complicated procedural history, and resulted in very high statutory damages, in several circuits. For instance, in a First Circuit case concerning the use of a file-sharing software to distribute thirty copyrighted songs belonging to the plaintiffs, the award against the defendant was $\$ 675,000$ in statutory damages, even though there was no monetary benefit for the infringer. ${ }^{220}$ The Court considered the jury award "wholly out of proportion with the government's legitimate interests in compensating the plaintiffs and deterring unlawful file-sharing" and reduced the award to $\$ 2,250$ for each work infringed. 221 On appeal, the plaintiffs presented testimony regarding the loss in value of the copyrights at issue and the harm of defendant's actions, such as reduced profits and job loss.222 Even though the defendant argued that "statutory damages cannot be awarded unless reasonably related to actual damages," the appeal court underlined that "the availability of statutory damages is not contingent on the demonstration of actual damages" and reinstated the jury's award of damages.223

The defendant moved for a new trial, arguing that "the court should remit the award to the statutory minimum because its excessiveness both offended due

216 Krist v. Scholastic, Inc., 415 F. Supp. 3d 514, 537 (E.D. Pa. 2019).

217 McGucken v. Newsweek LLC, 464 F. Supp. 3d 594, 609-10 (S.D.N.Y. 2020).

218 Seelie v. Original Media Grp. LLC, No. 19-cv-5643, 2020 WL 136659 (BMC), at *9 (E.D.N.Y. Jan. 12, 2020).

219 Epic Tech, LLC v. Lara, No. 4:15-cv-01220, 2017 WL 5903331 (S.D. Tex. Nov. 30, 2017).

220 Sony BMG Music Ent. v. Tenenbaum, 721 F. Supp. 2d 85, 87 (D. Mass. 2010).

221 Id. at 121.

222 Sony BMG Music Ent. v. Tenenbaum, 660 F.3d 487, 502-03 (1st Cir. 2011).

223 Id. at $506-07$. 
DeMO2 (Do Not DeleTE) 1 1/12/2021 5:42 AM

process and merited common law remittitur." 224 The court noted that remittitur is appropriate only where the award exceeds "any rational appraisal or estimate of the damages that could be based on the evidence before the jury."'225 Taking into consideration the harms intended to address, the particular behavior of the plaintiff, and the fact that the award was within the range for willful infringement, the court did not consider the award "wholly disproportioned to the offense."226

On appeal, the defendant claimed the award was so large that it violated his constitutional right to due process of law because the award of $\$ 675,000$ is not related to the actual injury caused, which was estimated at $\$ 450$ (the cost of 30 albums at $\$ 15$ each). ${ }^{227}$ The Court of Appeals, however, emphasized that the defendant "carried on his activities for years in spite of numerous warnings, he made thousands of songs available illegally, and he denied responsibility during discovery," and discussed of the deterrent effect of the statutory damage awards. Consequently, the Court held "that an award of $\$ 22,500$ per song, an amount that represents just $15 \%$ of the maximum award for willful violations ..., comports with due process."

The level of an award, deemed "monstrous and shocking," 228 was also extensively debated in the Eighth Circuit, in Capitol Records v. Thomas-Rasset, another case with a very long trial history. 229 The defendant infringed copyrighted works by illegally downloading and distributing the works via the online peer-to-peer file sharing application KaZaA. ${ }^{230}$ The defendant violated plaintiffs' exclusive rights of reproduction and distribution by downloading, distributing, and making available for distribution twenty-four copyrighted sound recordings. 231 The initial amount awarded was $\$ 222,000$; the District Court agreed to a new trial, and under different instructions the second jury awarded statutory damages of $\$ 1,920,000$. The District Court, however, remitted the award of the much lower amount of $\$ 54,000$. The third jury's award was $\$ 1,500,000$, but the District Court held that the maximum amount permitted by the Due Process Clause of the Fifth Amendment was $\$ 54,000$. The award was reduced accordingly. ${ }^{232}$ On appeal, the plaintiffs requested the amount initially

224 Sony BMG Music Ent. v. Tenenbaum, No. 07-11446-RWZ, 2012 WL 3639053, at *1

(D. Mass. Aug. 23, 2012).

225 Id. at 2.

$226 I d$. at 6.

227 Sony BMG Music Ent. v. Tenenbaum, 719 F.3d 67 (1st Cir. 2013).

228 Capitol Records, Inc. v. Thomas-Rasset, 680 F. Supp. 2d 1045, 1049 (D. Minn. 2010).

229 See Capitol Records, Inc. v. Thomas, 579 F. Supp. 2d 1210 (D. Minn. 2008); Capitol Records, Inc., 680 F.Supp. 2d at 1045; Capitol Records, Inc. v. Thomas-Rasset, 799 F. Supp. 2d 999 (D. Minn. 2011).

230 Capitol Records, Inc. v. Thomas-Rasset, 692 F.3d 899, 902-903 (8th Cir. 2012).

231 Id. at 904.

232 Id. at $903-905$. 
awarded, $\$ 222,000.233$ The Court held that the defendant's “willful infringement and subsequent efforts to conceal her actions certainly show 'a proclivity for unlawful conduct."'234 The Eighth Circuit Court of Appeals vacated the District Court judgment and remanded the case with directions to enter a judgment for $\$ 222,000$ in damages. 235

There are cases where the maximum statutory amount is nevertheless awarded based on several aggravating factors. In Sony/ATV Music Publishing v. 1729172 Ontario, for example, the Court underlined the defendants' "years of willful infringement," repeated disregard of Court's orders, refusal to provide financial documents, and failure to pay the sanctions for contempt, and held that the maximum statutory damages of $\$ 150,000.00$ per infringement was appropriate against the defendants. ${ }^{236}$ Another compelling array of aggravating factors that justify the award of the maximum statutory damages can be found in the Federal Court of Canada's decision in Adobe Systems v. Dale Thompson. ${ }^{237}$ The defendant's online selling of counterfeited reproductions of protected works, with "strong intention to infringe," bad faith, and refusal to acknowledge any wrongdoing, as well as the "need for deterrent relief." 238

Statutory damages can also be awarded against persons or organization for contributory infringement (the defendant knew or had reason to know of the infringement, contributes to, authorizes, or induces the infringement) and vicarious liability (the defendant can supervise the misconduct and benefits directly from the infringement). In certain circumstances, these regard Internet and cable TV providers or social media companies.

In this regard, an instructive illustration can be found in a case brought to the Eastern District of Virginia. 239 The plaintiffs, with the help of an anti-piracy company, demonstrated that their protected works were infringement by the users of the defendant's Internet service. In contrast, the defendants contributed to the infringing activity because they were willfully blind to the infringement occurring on its website. ${ }^{240}$ The defendants were found to have willfully infringed 10,017 copyrighted works; the jury awarded $\$ 99,830.29$ for each work

\footnotetext{
233 Id. at 902.

234 Id. at 906-08 (applying the Williams standard and concluding that an award of \$9,250 per each of 24 works is not so severe and oppressive as to be wholly disproportionate to the offense and obviously unreasonable).

235 Id. at 910.

236 Sony/ATV Music Pub. LLC v. 1729172 Ontario, Inc., No. 3:14-cv-1929, 2018 WL 4007537 at $* 9$ (M.D. Tenn. Aug. 20, 2018).

237 Adobe Sys. Inc. v. Dale Thompson DBA Appletree Sols., [2012] F.C. 1219, para. 5 (Can. Ont.).

238 Id. at 197 7-8.

239 Sony Music Ent.. v. Cox Comm., Inc., 426 F. Supp. 3d 217, 235-236 (E.D. Va. 2019).

240 Id.
} 


DeMO2 (Do Not DeleTE) 1 1/12/2021 5:42 AM

infringed, resulting in statutory damages of about $\$ 1$ billion..$^{241}$

\section{Award Adjustment}

The multiplication of the number of works infringed on the award for each infringement can lead to very high awards. The CCA is the only statute that provides for the application of the award limitation or adjustment. ${ }^{242}$ The application leads to a "cap" and precludes the award of exaggerated damages. For example, the adjustment application was encountered in a dispute decided by the Ontario Superior Court. ${ }^{243}$ In the case, about 150,000 works were infringed, and the statutory award could have amounted to more than C $\$ 75$ million. However, the Court held that such an award would be highly disproportionate and reduced the award to $\mathrm{C} \$ 2$ per infringed work, for a total of about $\mathrm{C} \$ 300,000 .{ }^{244}$

A similar approach can be found in Telewizja Polsat Canada Inc. v. Radiopol, where the plaintiffs requested the maximum statutory damages for each of the 2,009 programs infringed. ${ }^{245}$ The Federal Court of Canada, however, considered that it would be "out of proportion" to the infringements and applied the statutory adjustment; the Court took into consideration the deterrence need, defendants' "bad faith and complete disregard for the plaintiffs' litigation, their offers of settlement and to the Court process," and awarded statutory damages of $\mathrm{C} \$ 150$ per work, for a total award of $\mathrm{C} \$ 301,350.246$

\section{E. PUNITIVE DAMAGES}

Punitive or exemplary damages are criticized by prominent legal commentators as going beyond the unjust nature of restitution of copyright law, ${ }^{247}$ being unjust, over-compensatory, and unnecessary. ${ }^{248}$ However, if the copyright owner would receive, for instance, just the fee for the licensing of the work in the case, the defendant will be enticed to infringe with impunity, under the understanding that the maximum payable, if caught, will not exceed the regular amount, as per the market value. Moreover, there are cases where the defendant may rationally determine that the risk of being sued is worth the access

241 Sony Music Ent. v. Cox Comm., Inc., No. 118-cv-00950-LO-JFA, (E.D. Va., June 2, 2020).

242 CCA 38.1(3)(b).

243 Trader Corp. v. CarGurus Inc., [2017] ONSC 1841 (Can.).

244 Id. para. 67.

245 Telewizja Polsat Can. Inc. v. Radiopol Inc., [2006] F.C. 584 (Can.).

246 Id. para. 13, 31.

247 Peter S. Menell, Mark A. Lemley \& Robert P. Merges, Intellectual Property in the New Technological Age: 2018 (2018) at 838.

248 Patrick R. Goold, Corrective Justice and Copyright Infringement, 16 VAND. J. ENT. \& TECH. L. 251, 285 (2014). 
to unlimited pirated works. ${ }^{249}$ Consequently, recent proposals aim to increase the punitive damages significantly to better address the complex issues surrounding copyright infringement. ${ }^{250}$

Where available, punitive damages are awarded with a view to deter people from engaging in conduct similar to the one that forms the basis of the lawsuit. According to the U.S. Supreme Court, punitive damages "are private fines levied by civil juries to punish reprehensible conduct and to deter its future occurrence." 251 The Federal Court of Canada stated a similar view: "punitive damages are not intended to compensate, but to punish." 252

Punitive damages are awarded only in special cases. When the defendant's conduct can be construed as malicious, reckless, or oppressive, these awards allow the plaintiff to recover damages in addition to compensatory damages. Taking into account the vulnerability of copyrighted works to misconduct, punitive damages are not infrequently awarded. Such awards can truly provide effective compensation for the damage suffered by the plaintiff, as actual loss and loss of profits awards can be under-compensating and do not always accomplish full restitution. Therefore, punitive damages can "fill the gaps" and adequately compensate the plaintiffs, especially in cases of "egregious misconduct for the components of intangible, unquantifiable and exceptional losses that may be missed in the computation of recoverable compensatory damages," 253 and also provide "a deterrent against future unlawful behavior." 254

One of the most compelling arguments in favor of punitive damages was formulated by the Southern District of New York: "Where the contemplated award is actual damages plus profits, such a recovery is compensatory only and does not address the interests of deterrence and punishment that are reflected in the principles underlying both punitive damages and statutory damages for willful infringement." 255 As punishment, these damages impose on wrongdoers who inflict particularly acute, intentional, or wanton harm a sort of kind of

249 Glacier Films (USA), Inc. v. Turchin, 896 F.3d 1033 (9th Cir. 2018) (noting that the defendant kept using BitTorrent to pirate protected content even after he received notice that he faces legal penalties).

250 See National Copyright Administration, Copyright Law of the People's Republic of China (Revision Draft, Submission Version), Chinese Copyright and Media, WorDPREsS, https://chinacopyrightandmedia.wordpress.com/2014/06/06/copyright-law-of-the-

peoples-republic-of-china-revision-draft-submission-version/ (last visited Nov. 30, 2020). Art. 53 of the Draft Amendment to the People's Republic of China Copyright Law (CCL), proposed as a replacement to Art. 49 of the current CCL, would quintuple punitive damages possible for intentional infringement; see Lian Lu, Punitive damages introduced into the Draft of the Amended Copyright Law of China, Weblog post. IPK at Weblog, May 26 (2020).

251 Gertz v. Robert Welch, Inc., 418 U.S. 323, 350 (1974).

252 Thomson v. Afterlife Network, Inc., [2019] F.C. 545, para. 73 (Can.).

253 TVT Records v. Island Def Jam Music Grp., 279 F. Supp. 2d 413, 426 (S.D.N.Y. 2003).

254 SAS Inst., Inc. v. World Programming Ltd., 874 F.3d 370, 385 (4th Cir. 2017).

255 TVT Records v. Island Def Jam Music Grp., 262 F. Supp. 2d 185, 186 (S.D.N.Y. 2003). 
DeMO2 (Do Not DeleTE) 1 1/12/2021 5:42 AM

"quasi-criminal" penalty, in the form of "private fines." 256 The award of punitive damages benefits the victim, as well as the general public, as it provides a "measured and socially recognized outlet for retribution," which "achieves greater deterrence than restitutional awards limited to compensation for the particular injuries the wrongdoer inflicted." 257

Punitive or exemplary damages also serve other important purposes: they play an educational role, by underlining the severity of the infringement through enhanced awards, to "punish egregious malfeasance and deter the offender and potentially other persons from engaging in similar wrongful conduct," and to "remove the transgressor's incentive and profitability from engaging in aggravated misconduct." ${ }^{258}$ Further, punitive damages serve a compensatory law enforcement function, by reducing the probability that significant infringement will go unpunished, as "the prospect of significantly larger recovery is likely to induce more injured parties to vindicate their rights, and indirectly the rights of others, thereby off-setting any underenforcement by other victims," and by stimulating the victims to seek such awards. ${ }^{259}$

Courts employ a variety of analysis methods to determine the appropriate amount of a punitive damage award. While excessive awards are prohibited by all courts, what can be deemed as such is not agreed upon. ${ }^{260}$ The Federal Court of Canada, for instance, stated that punitive damages "are exceptional," awarded where a "party's conduct has been malicious, oppressive and highhanded and offends the court's sense of decency and where other remedies are not sufficient to accomplish the objectives of retribution, deterrence, and denunciation."261 In a Supreme Court of Canada judgment on the availability of punitive damages, the Court underlined that there is no such thing as "a fixed cap or fixed ratio between compensatory and punitive damages" and stated that the focus should be "not on the plaintiff's loss but on the defendant's misconduct," and that the "mechanical or formulaic approach" cannot allow the taken into consideration of "the many variables that ought to be taken into account in arriving at a just award." 262 The Supreme Court of Canada, in Cinar Corporation v. Robinson, also underlined that punitive damages need to "fully reflect the gravity of the conduct and the need to deter others from engaging in similar conduct," and that amount awarded must "reach] an appropriate balance between the overarching principle of restraint that governs these damages, on the one hand, and the need to deter

\footnotetext{
256 TVT Records, 279 F. Supp. 2d at 423.

257 Id.

258 Id. at 423-4.

259 Id. at 424.

260 Gotanda, supra note 14, at 442.

261 Young v. Thakur, [2019] F.C. 835, para. 52 (Can.).

262 Whiten v. Pilot Ins. Co., [2002] 1 S.C.R. 595, 636 (Can.).
} 
conduct of this gravity, on the other." 263

In EMI Christian Music v. MP3tunes, for an illustration, the plaintiff alleged that the defendants created a cyberlocker for storing digital music and a search service, which were used to infringe thousands of copyright-protected sound recordings and musical compositions. ${ }^{264}$ The defendants had "red-flag knowledge of, or was willfully blind to, infringing activity involving those categories of protected material." 265 In addition to statutory damages, the jury awarded $\$ 7.5$ million in punitive damages against the CEO of MP3tunes. ${ }^{266}$ The District Court, taking into account a number of the factors, such as the reprehensibility of defendant's misconduct, actual or potential harm inflicted, and awards in comparable cases, reduced the award to $\$ 750,000.267$ On appeal, the defendant argued that the punitive award, even reduced, violated his right to due process. The Court of Appeals for the Second Circuit, however, found that reasoning unpersuasive. ${ }^{268}$

In a number of cases, the amount of punitive damages was very high, resulting in a rigorous analysis on appeal. In Bridgeport Music v. Justin Combs Pub., for example, the plaintiffs, owners of an infringed song, received respective shares of $\$ 3.5$ million in punitive damages. ${ }^{269}$ On appeal, the defendants argued, among other things, that the $\$ 3.5$ million punitive damages award was unconstitutionally excessive. ${ }^{270}$ The Court of Appeals for the Sixth Circuit agreed that the award should be deemed excessive, in light of the Supreme Court's guidelines, which comprise consideration of defendants' conduct, evaluation of the disparity between harm and award, and comparison with awards in comparable cases. ${ }^{271}$ The Court of Appeals further highlighted the compensatory and punitive damages "disparity," and held the award unconstitutional, mainly considering the large ratio of the overall damages award to punitive damages award, and that the compensatory damage award included a punitive element. ${ }^{272}$ Consequently, the Court remanded to the District Court, for a remittitur of the punitive damages verdict, or a new trial. ${ }^{273}$

The Federal Court of Canada in Thomson v. Afterlife adopted a similar approach. 274 The court ruled punitive damages should not be awarded, even

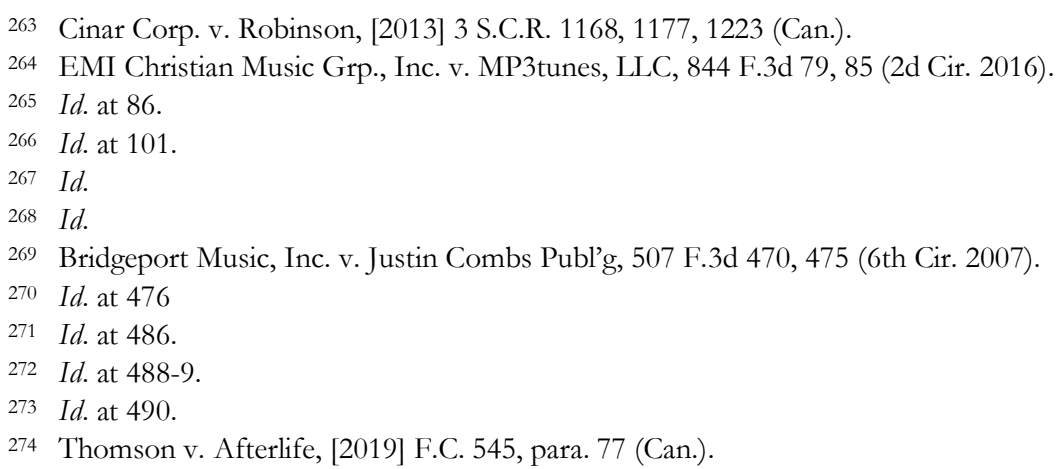


DeMO2 (Do Not DeleTE) 1 1/12/2021 5:42 AM

though the defendant's conduct could be "aptly characterized as 'obituary piracy,' [ ] high-handed, reprehensible[,] and represents a marked a marked departure from standards of decency." 275 The court stated statutory damages $(C \$ 10,000,000)$ and aggravated damages $(C \$ 10,000,000)$ were enough "to denounce and deter" the defendant's conduct. ${ }^{276}$ Repeat offending, however, can be grounds for statutory damages and punitive damages, as illustrated by Microsoft Corporation v. Liu. ${ }^{277}$ Microsoft and the defendant had settled in 2010 and in 2012 instances of copyright infringement. Nevertheless, in 2013, the defendant reproduced and copied Microsoft software and sold unlicensed copies of them. The Court evidenced that the defendant breached the settlement agreements and granted $\mathrm{C} \$ 10,000$ for each infringement, for a total of $\mathrm{C} \$ 50,000$. Punitive damages of $\mathrm{C} \$ 50,000$ were also awarded, motivated by the defendant's disregard for Court's prior injunction, "disrespect and contempt" for the Court that "cannot be tolerated or condoned," 278 and by the need to deter future infringement. ${ }^{279}$

\section{SUMMARY OF THE FINDINGS AND PROPOSALS}

The award of damages in cases of copyright infringement aims to provide compensation, to avoid unjust enrichment, and to protect, in general, creativity and property rights. Compensatory awards can take the form of lost profits or reasonable royalties and the illicit profits made by the infringer, or statutory damages.

Lost profits are often difficult and costly to demonstrate, particularly any indirect profits. While there are a number of elaborated methodologies that can be employed to calculate lost profits, none is widely accepted, or universally applicable, as the circumstances of each case are specific. In practice, this situation poses problems, as it allows for over-claiming, inconsistency, and inefficiency. Regarding the royalties, where a licensing fee is used to establish the award, there is no agreement if a multiplier should be used, and would be appropriate value of it. Concerning the disgorgement of profits, there are no clear guidelines or procedures on how the plaintiffs can apportion the infringer's gross revenue. In cases where the plaintiffs over-stated their losses, a reduction of the actual award can, and should, be considered.

The most significant jurisdictional difference concerns the availability of statutory and punitive damages. On the other hand, there are notable differences regarding statutory award range, calculation methodology, factors considered in

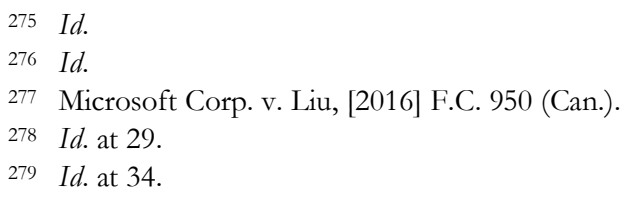


statutory and punitive damages, and existence of an award adjustment.

The analysis of copyright infringement cases revealed a number of characteristics that are not desirable in litigation: over-claiming, over-deterrence, convoluted procedures, ambiguity, lack of rules related to calculation, and inconsistency. The analysis of statutory damage awards exposed various, often contradicting, approaches to the use of multipliers and award calculation. There are also notable conflicting interpretations regarding the number of infringing works in the case of compilations and whether these should count as one or more copyright violations. Moreover, even when the number of works infringed is determined accurately, this does not allow for a direct conclusion regarding the adequate award of statutory damages. Further, the jurisprudence established that the per-work basis, the number of times the work in the case was infringed, for certain works like videos and computer programs should also be a factor.

The list of notable differences also regards the amount of statutory and punitive awards between the United States and the other common law jurisdictions. Several factors that are considered in these awards are extreme malice, negative effect on the infringed work owner's source of revenue, etc. In a number of cases, the enhanced awards were disproportionately high, even "monstrous," highlighting the need for statutory provisions that limit or "adjust," as a tool to avoid both excessive awards and overly complicated procedural histories.

A number of improvements might increase the predictability and efficiency of these trials. For determining the actual damage in cases of illegal download or streaming (e.g., movies or songs), a mechanical fee can be used. Where neither the causal nexus between the infringement and defendant's revenues nor the fair market value for the use of the infringed work can be determined, it cannot be held as insignificant. This is true even when the infringed work is not a prominent feature in the defendant's product. Therefore, at least the minimum statutory award should be awarded.

For more predictable and transparent procedures in cases of willful infringements, in order to be proportional or commensurate with the actual infringement circumstances statutory damages should be calculated by applying a formula which considers the severity of the following three factors: (i) magnitude of the infringement (i.e., number of works infringed, market value of the works infringed, effects on the claimant, and profits made by the infringer); (ii) method of infringement (e.g., access, hosting, distribution, etc.) and employment of sophisticated means; and (iii) infringer's misconduct (i.e., multiple infringements, continued infringement after notification, attempt to evade, etc.). For each of these three factors there would be determined, with reasonable precision or objectivity, a score. The total number resulted (the score) would be multiplied by the minimum statutory award to give the actual award in the case.

Punitive damages can play an important role in deterring misconduct and to properly compensating the claimants ("fill the gaps"), especially considering the 
challenges posed by the digital environment. A mathematical relationship between the compensatory and the punitive damages, or a multiplier of the former, for classes of misconduct would best serve the purposes of these awards, again considering the factors above (magnitude, method, and conduct).

\section{CONCLUSION}

Copyright law aims to protect creativity and innovation. The award of damages is an essential remedy in cases of unauthorized exploitation of protected works. The comprehensive cross-jurisdictional analysis proposed by this article extends the understanding of the issues surrounding the award of damages in cases of violation of the economic rights of copyright holders.

The findings of this article can be used to adjust the provisions regarding damage awards, to improve the litigation of copyright infringement cases, to increase the transparency and the precision of damage quantification, to elaborate educational materials, for professional programs or law school clinics, and to develop better prevention policies. The proposed improvements could lead to a more unified approach, increase the litigation outcome predictability, and better commensurate the award with the infringement. While this article considered only four jurisdictions, the findings can be of major interest to a global context, helping make the co-existence of different copyright systems easier. 